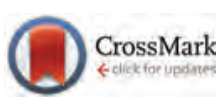

Cite this: Dalton Trans., 2017, 46, 471

\section{Synthesis and structural characterization of homochiral 2D coordination polymers of zinc and copper with conformationally flexible ditopic imidazolium-based dicarboxylate ligands $\uparrow$}

\author{
Antonio I. Nicasio, ${ }^{a}$ Francisco Montilla, ${ }^{\star a}$ Eleuterio Álvarez, ${ }^{b}$ Rosario P. Colodreroț \\ and Agustín Galindo*a
}

\begin{abstract}
Different novel coordination polymers containing zinc, 1-4, and copper, 5-8, metals, connected via chiral imidazolium-based dicarboxylate ligands, $\left[\mathrm{L}^{\mathrm{R}}\right]^{-}$, were isolated by reaction between zinc acetate or copper acetate and enantiomerically pure $\mathrm{HL}^{\mathrm{R}}$ compounds. They were characterised and structurally identified by $\mathrm{X}$-ray diffraction methods (single crystal and powder). These compounds are twodimensional homochiral coordination polymers, $\left[\mathrm{M}\left(\mathrm{L}^{\mathrm{R}}\right)_{2}\right]_{n}$, in which the metal ions are coordinated by the two carboxylate groups of $\left[\mathrm{L}^{\mathrm{R}}\right]^{-}$anions in a general bridging monodentate $\mu^{2}-\kappa^{1}-\mathrm{O}^{1}, \mathrm{\kappa}^{1}-\mathrm{O}^{3}$ fashion that afforded tetrahedral metal coordination environments for zinc, 1-4, and square planar for copper, 5-8, complexes. In all the compounds the 3D supramolecular architecture is constructed by non-covalent interactions between the hydrophobic parts (R groups) of the homochiral 2D coordination polymers and, in some cases, by weak $\mathrm{C}-\mathrm{H} \ldots \mathrm{O}$ non-classical hydrogen bonds that provided, in general, a dense crystal packing. DFT calculations on the $\left[\mathrm{L}^{\mathrm{R}}\right]^{-}$anions confirmed their conformational flexibility as ditopic linkers and this fact makes possible the formation of different coordination polymers for four-coordinated metal centers. Preliminary studies on the Zn-catalyzed synthesis of chiral $\alpha$-aminophosphonates were carried out and, unfortunately, no enantioselectivity was observed in these reactions.
\end{abstract}

Received 26th September 2016 Accepted 30th November 2016

DOI: $10.1039 / \mathrm{c} 6 \mathrm{dt} 03712 \mathrm{~g}$

www.rsc.org/dalton forward synthesis of chiral imidazolium-based dicarboxylic acids (Scheme 1). ${ }^{11-13}$ These compounds have also been employed as precursors of chiral NHC-carbene ligands ${ }^{14}$ and as chiral linkers in the construction of coordination polymers. In particular for the latter, compounds of manganese ${ }^{15}$ and zinc $^{16}$ with imidazolium-based dicarboxylate ligands derived from $\mathrm{L}$-alanine $\left(\mathrm{R}=\mathrm{Me}\right.$ in Scheme $\left.1, \mathrm{HL}^{\mathrm{Me}}\right)$ have been described. The possibility of forming enantiomerically pure metal coordination polymers or metal-molecular frameworks is particularly interesting in the emerging field of asymmetric

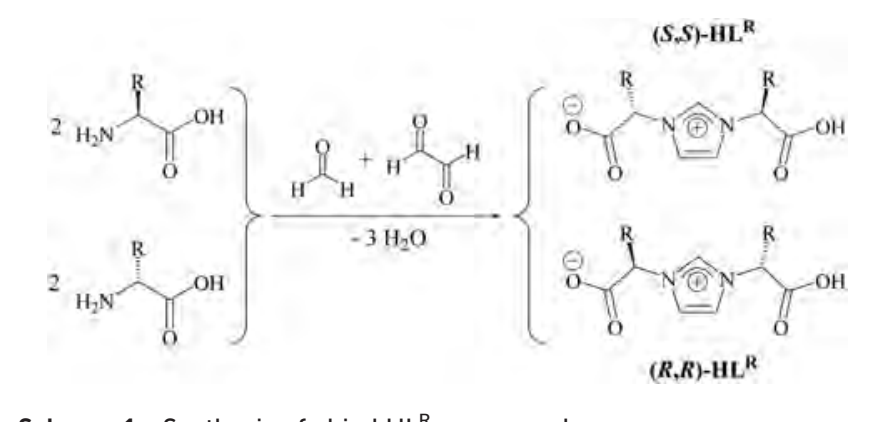

Scheme 1 Synthesis of chiral $\mathrm{HL}^{\mathrm{R}}$ compounds.

\footnotetext{
${ }^{a}$ Departamento de Quimica Inorgánica, Facultad de Química, Universidad de Sevilla, Aptdo 1203, 41071 Sevilla, Spain.E-mail: montilla@us.es, galindo@us.es

${ }^{b}$ Instituto de Investigaciones Quimicas, CSIC-Universidad de Sevilla, Avda. Américo Vespucio 49, 41092 Sevilla, Spain

$\dagger$ Electronic supplementary information (ESI) available: Crystal data, supramolecular packing, Rietveld plots, XRPD selected structural data of 1-3, TGA data, comparison between selected experimental and theoretical structural parameters, DFT optimised structures, energies and MOs. CCDC 1407226, 1407227 and 1493049-1493051. For ESI and crystallographic data in CIF or other electronic format see DOI: 10.1039/c6dt03712g

\$Permanent address: Departamento de Química Inorgánica, Universidad de Málaga, Campus Teatinos s/n, 29071-Málaga, Spain.
} 
catalysis, ${ }^{17,18}$ and, with these precedents, we become interested in the development of the coordination chemistry of chiral imidazolium-based dicarboxylic acids $\left(\mathrm{HL}^{\mathrm{R}}\right.$ in Scheme 1). Here, we describe the synthesis and structural characterization of novel homochiral coordination polymers of zinc, 1-4, and copper, 5-8, metals with the ditopic 1,3-bis (1-carboxylate-1-alkyl)imidazolium linkers $\left(\mathrm{HL}^{\mathrm{R}}, \mathrm{R}=\mathrm{Me},{ }^{\mathrm{i}} \mathrm{Pr}\right.$, $\left.\mathrm{CH}_{2} \mathrm{Ph}\right)$. Complexes containing $\left[\mathrm{L}^{\mathrm{iPr}}\right]^{-}$and $\left[\mathrm{L}^{\mathrm{CH}_{2} \mathrm{Ph}}\right]^{-}$ligands are the first structurally characterised examples of coordination polymers with such ligands.

\section{Experimental}

\section{General}

All preparations and other operations were carried out under aerobic conditions. Solvents were purified appropriately prior to use, using standard procedures. Chemicals were obtained from commercial sources and used as supplied. The compounds $(S, S)-\mathrm{HL}^{\mathrm{R}}$ were prepared according to the literature procedures. ${ }^{13}$ Infrared spectra were recorded on a PerkinElmer FT-IR Spectrum Two spectrophotometer (pressed $\mathrm{KBr}$ pellets). NMR spectra were recorded at the Centro de Investigaciones, Tecnología e Innovación (CITIUS) of the University of Sevilla by using Avance III spectrometers with ${ }^{13} \mathrm{C}$ $\left\{{ }^{1} \mathrm{H}\right\}$ and ${ }^{1} \mathrm{H}$ shifts referenced to the residual solvent signals. All data are reported in $\mathrm{ppm}$ downfield from $\mathrm{Si}\left(\mathrm{CH}_{3}\right)_{4}$. Polarimetry was carried out using a JASCO P-2000 digital polarimeter and the measurements were performed at room temperature (concentration of $c a .10 \mathrm{mg} \mathrm{mL} \mathrm{m}^{-1}$ ). Thermogravimetric Analyses (TGA) were carried out by the CITIUS of the University of Sevilla on a Q600 SDT TA instrument. Elemental analyses (C, H, N) and X-ray Powder Diffraction (XRPD) studies were conducted by the CITIUS of the University of Sevilla on an Elemental LECO CHNS 93 analyser and on a Bruker D8 advance A25 diffractometer, respectively. HPLC chromatograms were obtained on an Agilent 1260 Infinity instrument with a Chiralpak IA column at a flow rate of $0.5 \mathrm{~mL} \mathrm{~min} \mathrm{~m}^{-1}$ with heptane/isopropanol $=9 / 1(\mathrm{v} / \mathrm{v})$ and using a UV detector at $254 \mathrm{~nm}$.

\section{Syntheses}

$\left[\mathrm{Zn}\left((\boldsymbol{S}, \boldsymbol{S})-\mathrm{L}^{\mathrm{Me}}\right)_{2}\right]_{n}(\mathbf{1})$. This complex ${ }^{16}$ was prepared by a new experimental procedure: over a solution of $(S, S)-\mathrm{HL}^{\mathrm{Me}}$ $(0.2122 \mathrm{~g}, 1 \mathrm{mmol})$ in a $3: 1 \mathrm{mixture}$ of $\mathrm{EtOH} / \mathrm{H}_{2} \mathrm{O}$ was added a solution of zinc(II) acetate dihydrate $(0.1098 \mathrm{~g}, 0.5 \mathrm{mmol})$ in EtOH. The resulting mixture was stirred at $70{ }^{\circ} \mathrm{C}$ for 1 hour. The resulting white-yellowish solid was isolated by filtration and washed with $\mathrm{EtOH}$ and $\mathrm{Et}_{2} \mathrm{O}$ and dried. Crystallization from a $1: 3$ mixture of $\mathrm{H}_{2} \mathrm{O} / \mathrm{DMF}$ afforded uncoloured crystals of compound $1\left(0.145 \mathrm{~g}, 59 \%\right.$ yield). IR $\left(\mathrm{KBr}, \mathrm{cm}^{-1}\right)$ : 3442 (w, br), 3139 (w), 1632 (vs, br), 1560 (m), 1464 (m), 1391 (s), 1363 (s), $1248(\mathrm{w}), 1172(\mathrm{~s}), 1111(\mathrm{w}), 1075(\mathrm{w}), 1025(\mathrm{w}), 974$ (w), $881(w), 741(w), 712(w), 682(w), 525(w), 510(w) .{ }^{1} \mathrm{H}$ NMR $\left(\mathrm{D}_{2} \mathrm{O}, 300 \mathrm{~Hz}\right): \delta 1.73\left(\mathrm{~d},{ }^{3} J_{\mathrm{HH}}=7.5 \mathrm{~Hz}, 6 \mathrm{H}, \mathrm{CH}_{3}\right), 4.96$ (q, $\left.{ }^{3} J_{\mathrm{HH}}=7.5,2 \mathrm{H}, \mathrm{CHCH}_{3}\right), 7.48(\mathrm{~s}, 2 \mathrm{H}, \mathrm{NCHCHN}), 8.83(\mathrm{~s}, 1 \mathrm{H}$,
NCHN). ${ }^{13} \mathrm{C}\left\{{ }^{1} \mathrm{H}\right\}$ NMR $\left(\mathrm{D}_{2} \mathrm{O}, 75.47 \mathrm{~Hz}\right): \delta 17.5\left(\mathrm{~s}, \mathrm{CH}_{3}\right), 60.2$ (s, $\left.\mathrm{CHCH}_{3}\right), 123.5$ (s, $\left.\mathrm{NCHCHN}\right), 134.7$ (s, NCHN), 175.5 (COO). Elemental Anal. Calc. for $\mathrm{ZnC}_{18} \mathrm{H}_{22} \mathrm{~N}_{4} \mathrm{O}_{8}$ : C, 44.32; H, 4.49; $\mathrm{N}, 11.35$. Found: C, $44.53 ; \mathrm{H}, 4.55 ; \mathrm{N}, 11.49 \%$.

$\left[\mathrm{Zn}\left((S, S)-\mathrm{L}^{\mathrm{iPr}}\right)_{2} \cdot \mathrm{H}_{2} \mathrm{O}\right]_{n}(2)$ and $\left[\mathrm{Zn}\left((R, R)-\mathrm{L}^{\mathrm{iPr}}\right)_{2} \cdot \mathrm{H}_{2} \mathrm{O}\right]_{n}$ (3). Over a solution of $(S, S)-\mathrm{HL}^{\mathrm{iPr}}(0.2683 \mathrm{~g}, 1 \mathrm{mmol})$ in a $3: 1$ mixture of EtOH $/ \mathrm{H}_{2} \mathrm{O}$ was added a solution of zinc(II) acetate dihydrate $(0.1097 \mathrm{~g}, 0.5 \mathrm{mmol})$ in EtOH. The resulting mixture was stirred at $60{ }^{\circ} \mathrm{C}$ for 1 hour. The solvent was evaporated and the resulting oil was dissolved in a 1:3 mixture of $\mathrm{H}_{2} \mathrm{O} /$ DMF. Slow evaporation of this solution afforded uncoloured crystals of compound $\left[\mathrm{Zn}\left((S, S)-\mathrm{L}^{\mathrm{iPr}}\right)_{2} \cdot \mathrm{H}_{2} \mathrm{O}\right]_{n}$ (2) (0.960 g, 31\% yield). IR $\left(\mathrm{KBr}, \mathrm{cm}^{-1}\right)$ : 3494 (m, br), 3138 (m), 2966 (s), 2877 (m), 1639 (vs), 1560 (m), 1470 (m), 1423 (m), 1375 (vs), 1242 (w), 1184 (w), $1160(\mathrm{~m}), 1108(\mathrm{w}), 1021(\mathrm{w}), 982(\mathrm{w}), 920(\mathrm{w}), 843(\mathrm{w}), 818$ $(\mathrm{w}), 754(\mathrm{~m}), 717(\mathrm{w}), 650(\mathrm{w}), 501(\mathrm{w}), 452(\mathrm{w}), 401(\mathrm{w}) \cdot[\alpha]_{\mathrm{D}}^{25}=$ $+105.1\left(\mathrm{H}_{2} \mathrm{O}\right) .{ }^{1} \mathrm{H}$ NMR $\left(\mathrm{D}_{2} \mathrm{O}, 300 \mathrm{~Hz}\right): \delta 0.91\left(\mathrm{~d},{ }^{3} J_{\mathrm{HH}}=7.5 \mathrm{~Hz}\right.$, $\left.6 \mathrm{H}, \mathrm{CHCH}_{3}\right), 1.01\left(\mathrm{~d},{ }^{3} J_{\mathrm{HH}}=7.5 \mathrm{~Hz}, 6 \mathrm{H}, \mathrm{CHCH}_{3}\right), 2.39\left(\mathrm{o},{ }^{3} J_{\mathrm{HH}}\right.$ $\left.=7.5 \mathrm{~Hz}, 2 \mathrm{H}, \mathrm{CHCH}_{3}\right), 4.53\left(\mathrm{~d},{ }^{3} J_{\mathrm{HH}}=7.5 \mathrm{~Hz}, 2 \mathrm{H}, \mathrm{CHCHCH}_{3}\right)$, $7.52(\mathrm{~s}, 2 \mathrm{H}, \mathrm{NCHCHN}), 8.90(\mathrm{~s}, 1 \mathrm{H}, \mathrm{NCHN}) .{ }^{13} \mathrm{C}\left\{{ }^{1} \mathrm{H}\right\} \mathrm{NMR}$ $\left(\mathrm{D}_{2} \mathrm{O}, 75.47 \mathrm{~Hz}\right): \delta 17.5\left(\mathrm{~s}, \mathrm{CHCH}_{3}\right), 18.6\left(\mathrm{~s}, \mathrm{CHCH}_{3}\right), 31.1$ (s, $\left.\mathrm{CHCH}_{3}\right), 71.5$ (s, $\left.\mathrm{CHCHCH}_{3}\right), 122.0$ (s, $\left.\mathrm{NCHCHN}\right), 135.7$ (s, NCHN), 173.8 (s, COO). Elemental Anal. Calc. for $\mathrm{ZnC}_{26} \mathrm{H}_{38} \mathrm{~N}_{4} \mathrm{O}_{8} \cdot \mathrm{H}_{2} \mathrm{O}: \mathrm{C}, 50.53 ; \mathrm{H}, 6.52 ; \mathrm{N}, 9.07$. Found: C, 50.39; $\mathrm{H}, 6.33 ; \mathrm{N}, 8.97 \%$. Following the same procedure, starting from $(R, R)-\mathrm{HL}^{\mathrm{iPr}}(1 \mathrm{mmol})$, was obtained complex $[\mathrm{Zn}((R, R)-$ $\left.\left.\mathrm{L}^{\mathrm{iPr}}\right)_{2} \cdot \mathrm{H}_{2} \mathrm{O}\right]_{n}$ (3) $\left(0.944 \mathrm{~g}, 59 \%\right.$ yield). IR $\left(\mathrm{KBr}, \mathrm{cm}^{-1}\right): 3440$ (vs, br), $3129(\mathrm{~m}), 2966(\mathrm{~s}), 2878(\mathrm{w}), 1643(\mathrm{vs}), 1563(\mathrm{w}), 1470(\mathrm{w})$, $1424(\mathrm{~m}), 1384$ (vs), 1346 (m), 1247 (w), 1155 (s), 1117 (w), 1024 (w), $985(w), 922(w), 844(w), 819(w), 753(\mathrm{~s}), 718(w), 649(w)$, 512 (vw, br). $[\alpha]_{\mathrm{D}}^{24}=-103.8\left(\mathrm{H}_{2} \mathrm{O}\right) .{ }^{1} \mathrm{H}$ NMR $\left(\mathrm{D}_{2} \mathrm{O}, 300 \mathrm{~Hz}\right)$ : $\delta 0.77\left(\mathrm{~d},{ }^{3} J_{\mathrm{HH}}=7.5 \mathrm{~Hz}, 6 \mathrm{H}, \mathrm{CH}_{3}\right), 0.88\left(\mathrm{~d},{ }^{3} \mathrm{~J}_{\mathrm{HH}}=7.5 \mathrm{~Hz}, 6 \mathrm{H}\right.$, $\left.\mathrm{CH}_{3}\right), 2.38\left(\mathrm{o},{ }^{3} J_{\mathrm{HH}}=7.5 \mathrm{~Hz}, 2 \mathrm{H}, \mathrm{CHCH}_{3}\right), 4.51\left(\mathrm{~d},{ }^{3} J_{\mathrm{HH}}=\right.$ $\left.7.5 \mathrm{~Hz}, 2 \mathrm{H}, \mathrm{CHCHCH}_{3}\right), 7.50(\mathrm{~s}, 2 \mathrm{H}, \mathrm{NCHCHN}), 8.89(\mathrm{~s}, 1 \mathrm{H}$, $\mathrm{NCHN}) \cdot{ }^{13} \mathrm{C}\left\{{ }^{1} \mathrm{H}\right\}$ NMR $\left(\mathrm{D}_{2} \mathrm{O}, 75.47 \mathrm{~Hz}\right): \delta 17.4\left(\mathrm{~s}, \mathrm{CHCH}_{3}\right)$, $18.6\left(\mathrm{~s}, \mathrm{CHCH}_{3}\right), 31.1\left(\mathrm{~s}, \mathrm{CHCH}_{3}\right), 71.4\left(\mathrm{~s}, \mathrm{CHCHCH}_{3}\right), 122.0$ (s, NCHCHN), 135.7 (s, NCHN), 173.8 (s, COO). Elemental Anal. Calc. for $\mathrm{ZnC}_{26} \mathrm{H}_{38} \mathrm{~N}_{4} \mathrm{O}_{8} \cdot 2 \mathrm{H}_{2} \mathrm{O}$ : C, $49.10 ; \mathrm{H}, 6.66 ; \mathrm{N}, 8.81$. Found: C, 49.21; H, 6.40; N, 8.94\%.

$\left[\mathrm{Zn}\left((\mathrm{S}, \mathrm{S})-\mathrm{L}^{\mathrm{CH}_{2} \mathrm{Ph}}\right)_{2} \cdot 2 \mathrm{DMF} \cdot \mathrm{H}_{2} \mathrm{O}\right]_{n}$ (4). Over a solution of $\mathrm{HL}^{\mathrm{CH}_{2} \mathrm{Ph}}(0.1822 \mathrm{~g}, 0.5 \mathrm{mmol})$ in $\mathrm{MeOH}(5 \mathrm{~mL})$ was added a solution of zinc(II) acetate dihydrate $(0.0549 \mathrm{~g}, 0.25 \mathrm{mmol})$ in $\mathrm{MeOH}$. The resulting mixture was stirred at $80{ }^{\circ} \mathrm{C}$ for 3 hours. The solution was evaporated and the resulting oil was dissolved in DMF. Slow evaporation of this solution resulted in the formation of uncoloured crystals of compound $[\operatorname{Zn}((S, S)$ $\left.\left.\mathrm{L}^{\mathrm{CH}_{2} \mathrm{Ph}}\right)_{2} \cdot 2 \mathrm{DMF} \cdot \mathrm{H}_{2} \mathrm{O}\right]_{n}$ (4) $(0.160 \mathrm{~g}, 67 \%$ yield $) . \mathrm{IR}\left(\mathrm{KBr}, \mathrm{cm}^{-1}\right)$ : 3460 (m, br), 3139 (m), 3101 (m), 3063 (m), 3030 (m), 2931 (s), 2864 (m), 1699 (m), 1664 (vs), 1642 (vs), 1557 (m), 1497 (m), $1455(\mathrm{~m}), 1411(\mathrm{~m}), 1385$ (s), $1345(\mathrm{~m}), 1298(\mathrm{~m}), 1182(\mathrm{w})$, $1162(\mathrm{~m}), 1096(\mathrm{~m}), 1031(\mathrm{w}), 962(\mathrm{w}), 944(\mathrm{w}), 926(\mathrm{w}), 841(\mathrm{w})$, $773(\mathrm{w}), 750(\mathrm{~m}), 724(\mathrm{~m}), 700(\mathrm{f}), 662(\mathrm{~m}), 571(\mathrm{w}), 502(\mathrm{w})$, $458(\mathrm{w}) \cdot[\alpha]_{\mathrm{D}}^{25}=-85.3^{\circ}\left(\mathrm{H}_{2} \mathrm{O}\right) .{ }^{1} \mathrm{H}$ NMR $\left(\mathrm{D}_{2} \mathrm{O}, 300 \mathrm{~Hz}\right): \delta 2.75$ (s, 3H, $\left.\mathrm{CH}_{3}, \mathrm{DMF}\right), 2.91\left(\mathrm{~s}, 3 \mathrm{H}, \mathrm{CH}_{3}, \mathrm{DMF}\right), 3.07\left(\mathrm{dd}, 2 \mathrm{H},{ }^{1} J_{\mathrm{HH}}=\right.$ $\left.14.5,{ }^{3} \mathrm{~J}_{\mathrm{HH}}=11 \mathrm{~Hz}, \mathrm{C} H \mathrm{H}^{\prime} \mathrm{Ph}\right), 3.41\left(\mathrm{dd}, 2 \mathrm{H},{ }^{1} \mathrm{~J}_{\mathrm{HH}}=14.5,{ }^{3} \mathrm{~J}_{\mathrm{HH}}=\right.$ $\left.4 \mathrm{~Hz}, \mathrm{CH} H^{\prime} \mathrm{Ph}\right), 4.95\left(\mathrm{dd}, 2 \mathrm{H},{ }^{1} J_{\mathrm{HH}}=11,{ }^{3} J_{\mathrm{HH}}=4 \mathrm{~Hz}\right.$, 
$\left.\mathrm{CHCH}_{2} \mathrm{Ph}\right), 6.90(\mathrm{~m}, 4 \mathrm{H}, \mathrm{CH}, \mathrm{Ph}), 7.18$ (m, 6H, CH, Ph), 7.20 (s, 2H, NCHCHN), 7.82 (s, 1H, HCO, DMF), 8.43 (s, 1H, NCHN). ${ }^{13} \mathrm{C}\left\{{ }^{1} \mathrm{H}\right\}$ NMR ( $\left.\mathrm{CD}_{3} \mathrm{OD}, 75.47 \mathrm{~Hz}\right): \delta 30.3\left(\mathrm{~s}, \mathrm{CH}_{3}, \mathrm{DMF}\right), 35.6$ (s, $\left.\mathrm{CH}_{3}, \mathrm{DMF}\right), 39.6$ (s, $\left.\mathrm{CH}_{2} \mathrm{Ph}\right), 66.3\left(\mathrm{~s}, \mathrm{CHCH}_{2} \mathrm{Ph}\right), 121.2$ (s, NCHCHN), 126.8, 128.5, 128.6 (s, CH, Ph), 136.1 (s, NCHN), 163.5 (s, HCO, DMF), 172.1 (s, COO). Elemental Anal. Calculated for $\mathrm{ZnC}_{42} \mathrm{H}_{38} \mathrm{~N}_{4} \mathrm{O}_{8} \cdot 2 \mathrm{DMF} \cdot \mathrm{H}_{2} \mathrm{O}$ : C, 60.28; $\mathrm{H}, 5.69$; N, 8.79\%. Found: C, 59.49; H, 5.62; N, 9.04\%. No good microanalytical results were obtained for this complex and the best one is stated here.

$\left[\mathbf{C u}\left((\boldsymbol{S}, \boldsymbol{S})-\mathrm{L}^{\mathrm{Me}}\right)_{2}\right]_{n}$ (5). Over a solution of $\mathrm{HL}^{\mathrm{Me}}(1.061 \mathrm{~g}$, $5 \mathrm{mmol})$ in a 3:1 mixture of $\mathrm{EtOH} / \mathrm{H}_{2} \mathrm{O}(3 \mathrm{~mL})$ was added copper(II) acetate dihydrate $(0.501 \mathrm{~g}, 2.5 \mathrm{mmol})$. The resulting mixture was stirred at $60^{\circ} \mathrm{C}$ for $2 \mathrm{~h}$. The solution was evaporated and the resulting oil was dissolved in a $1: 3$ mixture of $\mathrm{H}_{2} \mathrm{O} /$ DMF. Slow evaporation of this solution afforded blue crystals of compound $\left[\mathrm{Cu}\left((S, S)-\mathrm{L}^{\mathrm{Me}}\right)_{2}\right]_{n}$ (5) (0.9985 g, 82\% yield). IR (KBr, cm ${ }^{-1}$ ): 3135 (w), 2972 (w), 1651 (vs), 1565 (m), 1549 (m), 1462 (m), 1390 (s), 1361 (s), 1340 (s), 1258 (m), 1232 (m), $1166(\mathrm{~m}), 1101(\mathrm{w}), 1040(\mathrm{w}), 970(\mathrm{w}), 892(\mathrm{w}), 839(\mathrm{w}), 781(\mathrm{~m})$, $681(\mathrm{~m}), 638(\mathrm{w}) \cdot[\alpha]_{\mathrm{D}}^{25}=+62.4^{\circ}\left(\mathrm{H}_{2} \mathrm{O}\right) \cdot \mu_{\text {eff }}=1.72 \mu_{\mathrm{B}}$ at $26^{\circ} \mathrm{C}$. Elemental Anal. Calc. for $\mathrm{CuC}_{18} \mathrm{H}_{22} \mathrm{~N}_{4} \mathrm{O}_{8}$ : C, 44.49; H, 4.56; $\mathrm{N}, 11.53$. Found: C, 44.96; H, 4.35; N, $11.52 \%$.

$\left[\mathrm{Cu}\left((S, S)-\mathrm{L}^{\mathrm{iPr}}\right)_{2}\right]_{n}(6)$ and $\left[\mathrm{Cu}\left((R, R)-\mathrm{L}^{\mathrm{iPr}}\right)_{2}\right]_{n}(7)$. Following the same synthetic procedure of complex 5 were prepared these compounds starting from $\mathrm{HL}^{\mathrm{iPr}}(0.5 \mathrm{mmol})$ in $74 \%, 6$, and $50 \%, 7$, yield, respectively. $\left[\mathrm{Cu}\left((S, S)-\mathrm{L}^{\mathrm{iPr}}\right)_{2}\right]_{n}(6): \mathrm{IR}\left(\mathrm{KBr}, \mathrm{cm}^{-1}\right)$ : 3165 (vw), 2965 (s), 2875 (s), 1662 (m), 1639 (vs), 1468 (vw) 1366 (s), 1303 (m), 1230 (m), 1185 (w), 1153 (m), $1117(\mathrm{w})$, $919(\mathrm{w}), 854(\mathrm{vw}), 817(\mathrm{vw}), 759(\mathrm{~m}), 648(\mathrm{w}), 510(\mathrm{w}), 425(\mathrm{vw})$. $[\alpha]_{\mathrm{D}}^{25}=+112.2\left(\mathrm{H}_{2} \mathrm{O}\right) . \mu_{\text {eff }}=1.72 \mu_{\mathrm{B}}$ at $26^{\circ} \mathrm{C}$. Elemental Anal. Calc. for $\mathrm{CuC}_{26} \mathrm{H}_{38} \mathrm{~N}_{4} \mathrm{O}_{8}$ : C, 52.21; H, 6.40; N, 9.37. Found: C, 52.75; H, 6.27; N, 9.52\%. [Cu((R,R)-L $\left.\left.{ }^{\mathrm{iPr}}\right)_{2}\right]_{n}(7): \mathrm{IR}\left(\mathrm{KBr}, \mathrm{cm}^{-1}\right)$ : 3468 (s, br), 3217 (m), 3134 (m), 2965 (s), 2876 (w), $1662(\mathrm{~m})$, 1644 (vs), 1530 (m), 1467 (m) 1418 (m), 1384 (vs), 1315 (m), $1303(\mathrm{~m}), 1230(\mathrm{~m}), 1185(\mathrm{~m}), 1153(\mathrm{~s}), 1116(\mathrm{w}), 1029(\mathrm{w})$, $978(\mathrm{vw}), 919(\mathrm{w}), 853(\mathrm{~m}), 817(\mathrm{~m}), 759(\mathrm{~s}), 648(\mathrm{w}), 546(\mathrm{w})$, $509(\mathrm{w}), 476(\mathrm{w}), 424(\mathrm{w}) \cdot[\alpha]_{\mathrm{D}}^{25}=-107.2\left(\mathrm{H}_{2} \mathrm{O}\right) \cdot \mu_{\mathrm{eff}}=1.70 \mu_{\mathrm{B}}$ at $26{ }^{\circ} \mathrm{C}$. Elemental Anal. Calc. for $\mathrm{CuC}_{26} \mathrm{H}_{38} \mathrm{~N}_{4} \mathrm{O}_{8}: \mathrm{C}, 52.21 ; \mathrm{H}$, 6.40; N, 9.37. Found: C, 51.67; H, 6.38; N, 9.44\%.

$\left[\mathrm{Cu}\left((\boldsymbol{S}, \boldsymbol{S})-\mathrm{L}^{\mathrm{CH}_{2} \mathrm{Ph}}\right)_{2}\right]_{n}$ (8). Over a solution of $(S, S)-\mathrm{HL}^{\mathrm{CH}_{2} \mathrm{Ph}}$ $(0.1822 \mathrm{~g}, 0.5 \mathrm{mmol})$ in $\mathrm{MeOH}(5 \mathrm{~mL})$ was added a solution of sodium acetate $(0.0410 \mathrm{~g}, 0.5 \mathrm{mmol})$. Over this solution was added a solution of copper chloride dihydrate $(0.0426 \mathrm{~g}$, $0.25 \mathrm{mmol})$. The resulting mixture was stirred at $60{ }^{\circ} \mathrm{C}$ for $2 \mathrm{~h}$. A blue precipitate was formed and isolated by filtration. The solid was dissolved in hot $\mathrm{MeOH}(10 \mathrm{~mL})$ and DMF $(10 \mathrm{~mL})$ was added. Slow evaporation of this solution generated blue crystals of compound $\left[\mathrm{Cu}\left((S, S)-\mathrm{L}^{\mathrm{CH}_{2} \mathrm{Ph}}\right)_{2}\right]_{n}(\mathbf{8})$ in $20 \%$ yield. IR ( $\left.\mathrm{KBr}, \mathrm{cm}^{-1}\right): 3469(\mathrm{~m}, \mathrm{br}), 3150(\mathrm{~m}), 3130(\mathrm{~m})$, 3101 (m), 3064 (m), 3028 (m), 2929 (s), 1720 (w), 1645 (vs), $1564(\mathrm{~m}), 1550$ (m), 1497 (m), 1455 (m), 1419 (m), 1384 (s), 1347 (m), 1282 (m), 1253 (m), 1198 (m), $1184(\mathrm{~m}), 1155(\mathrm{w})$, $1104(\mathrm{~m}), 1084(\mathrm{~m}), 1032(\mathrm{w}), 944(\mathrm{w}), 894(\mathrm{w}), 862(\mathrm{w}), 833(\mathrm{w})$, $812(\mathrm{w}), 752(\mathrm{w}), 731(\mathrm{~m}), 701(\mathrm{~m}), 677(\mathrm{~m}), 636(\mathrm{~m}), 574(\mathrm{w})$, $504(\mathrm{w})$.

\section{X-ray crystallography}

A summary of the crystallographic data and structure refinement results for compounds $\mathbf{2 , 4 - 6}$ and $\mathbf{8}$ is given in Table S1. $\dagger$ Crystals of suitable size for X-ray diffraction analysis were coated with dry perfluoropolyether and mounted on glass fibers and fixed in a cold nitrogen stream $(T=213 \mathrm{~K})$ to the goniometer head. Data collection was performed on a BrukerNonius X8Apex-II CCD diffractometer, using monochromatic radiation $\lambda\left(\right.$ Mo $\left.K_{\alpha}\right)=0.71073 \AA$, by means of $\omega$ and $\varphi$ scans with a width of 0.50 degree. The data were reduced (SAINT ${ }^{19}$ ) and corrected for absorption effects by the multi-scan method (SADABS). ${ }^{20}$ The structures were solved by direct methods (SIR-2002 ${ }^{21}$ ) and refined against all $F^{2}$ data by full-matrix leastsquares techniques (SHELXL-2016/6 ${ }^{22}$ ) minimizing $\mathrm{w}\left[F_{\mathrm{O}}{ }^{2}-\right.$ $\left.F_{\mathrm{c}}{ }^{2}\right]^{2}$. All non-hydrogen atoms were refined anisotropically. The hydrogen atoms were included from the calculated positions and refined riding on their respective carbon atoms with isotropic displacement parameters. A search for solvent accessible voids in 2 and 8 crystals using PLATON-SQUEEZE ${ }^{23}$ showed potential solvent volumes of $486 \AA^{3}$ (equating to 9 molecules of water per unit cell) and $2116 \AA^{3}$ (equating to 42 molecules of water per unit cell), respectively, impossible to model even with the most severe restraints. The corresponding CIF data represent SQUEEZE treated structures with water molecules handling as a diffuse contribution to the overall scattering, without a specific atom position and excluded from the structural model. The SQUEEZE output results were embedded within the CIF by SHELXL-2016/6. CCDC 1407226 (2), 1493049 (4), 1493050 (5), 1407227 (6) and 1493051 (8) contain the supplementary crystallographic data for this paper.

\section{X-ray powder diffraction}

X-ray powder diffraction (XRPD) patterns were collected on a Bruker D8 advance A25 diffractometer in a Bragg-Brentano reflection configuration by using the LynxEye detector. A summary of the crystallographic data and structure refinement results for compounds 3 and 7 is given in Table S2. $\uparrow$ XRPD patterns were auto-indexed using the DICVOL06 program, ${ }^{24}$ in an orthorhombic cell for $\left[\mathrm{Zn}\left((R, R)-\mathrm{L}^{\mathrm{iPr}}\right)_{2} \cdot \mathrm{H}_{2} \mathrm{O}\right]_{n}$ (3) and in a triclinic unit cell for $\left[\mathrm{Cu}\left((R, R)-\mathrm{L}^{\mathrm{iPr}}\right)_{2}\right]_{n}(7)$. Their crystal structures were determined by the Rietveld method, ${ }^{25}$ using the structures of $\left[\mathrm{Zn}\left((S, S)-\mathrm{L}^{\mathrm{iPr}}\right)_{2} \cdot \mathrm{H}_{2} \mathrm{O}\right]_{n}$ (2) and $\left[\mathrm{Cu}\left((S, S)-\mathrm{L}^{\mathrm{iPr}}\right)_{2}\right]_{n}$ (6) as starting models, respectively. Rietveld refinement was carried out by using the GSAS package ${ }^{26}$ and the graphic interface EXPGUI $^{27}$ with soft constraints to maintain chemically reasonable geometries for the imidazolium moiety and the alkyl chain: $\mathrm{N} \cdots \mathrm{C}$ and $\mathrm{C} \cdots \mathrm{C}, 1.34(1), \mathrm{C} \cdots \mathrm{C}$ and $\mathrm{N} \cdots \mathrm{C}, 2.20(2), \mathrm{N}-\mathrm{C}$, 1.50(1) $\AA$ for the imidazolium group; and $\mathrm{C}-\mathrm{C}, 1.50(1), \mathrm{C} \cdots \mathrm{C}$, 2.50(2), $\mathrm{C} \cdots \mathrm{O}, 1.23(1), \mathrm{O} \cdots \mathrm{O}, 2.21(2)$, and $\mathrm{C} \cdots \mathrm{O}, 2.36(2) \AA$ for the $\mathrm{CH}\left[\left(\mathrm{CH}\left(\mathrm{CH}_{3}\right)_{2}\right)\right] \mathrm{COO}$ moiety. Hydrogen atoms were not included in the refinements. The final weight factors for the soft constraints were fixed at 10. Only one isotropic atomic displacement parameter was refined. 


\section{Computational details}

The electronic structure and geometries of the conformers of $\left[(S, S)-\mathrm{L}^{\mathrm{R}}\right]^{-}$anions $\left(\mathrm{R}=\mathrm{Me},{ }^{\mathrm{i}} \mathrm{Pr}, \mathrm{CH}_{2} \mathrm{Ph}\right)$ were computed using density functional theory at the B3LYP level, ${ }^{28}$ with the $6-311 \mathrm{G}+(\mathrm{d}, \mathrm{p})$ basis set for all the atoms. This combination of methods and basis sets provides a good structural description of the $(S, S)-\mathrm{HL}^{\mathrm{R}}$ compounds according to the comparison of the structural parameters of the optimised structures of $(S, S)$ $\mathrm{HL}^{\mathrm{Me}}$ and $(S, S)-\mathrm{HL}^{\mathrm{CH}_{2} \mathrm{Ph}}$ with those of the reported crystal structures (CSD refcodes LUYSAA and LUYRON, respectively; see Table S3 $\uparrow)^{12}$ The conformers of the enantiomerically related $\left[(R, R) \mathrm{L}^{\mathrm{iPr}}\right]^{-}$anion were also computed and the resulting structure and energies were compared with those of the $\left[(S, S)-\mathrm{L}^{\mathrm{iPr}}\right]^{-}$ anion. Since no noteworthy differences were found, other $\left[(R, R)-\mathrm{L}^{\mathrm{R}}\right]^{-}$anions were not theoretically analyzed. The molecular geometries of all $\left[\mathrm{L}^{\mathrm{R}}\right]^{-}$compounds were optimised without symmetry constraints. Frequency calculations were carried out at the same level of theory to identify all of the stationary points as minima (zero imaginary frequencies) and to provide thermal correction to free energies at $298.15 \mathrm{~K}$ and $1 \mathrm{~atm}$. DFT calculations were performed using the Gaussian 09 suite of programs. ${ }^{29}$ The Cartesian coordinates and energetic parameters of all optimised compounds are reported in the ESI. $\dagger$

\section{General procedure for the enantioselective $\mathrm{Zn}$-catalyzed synthesis of diethyl((4-methoxyphenyl)((4-methoxyphenyl) amino)methyl)phosphonate}

A reactor (a $50 \mathrm{~mL}$ vial equipped with a Young valve and containing a stirrer flea) was charged with 4-methoxybenzaldehyde ( $0.5 \mathrm{mmol})$, 4-methoxyaniline ( $0.5 \mathrm{mmol})$, diethyl phosphonate (0.5 mmol), Zn(II) coordination polymer 1 or $2(0.05 \mathrm{mmol})$ and the reaction solvent $(1 \mathrm{~mL})$ in the aforementioned order. Zn-Catalyzed in situ reactions were performed using the same procedure, but by introducing zinc acetate $(0.05 \mathrm{mmol})$ and
$\mathrm{HL}^{\mathrm{R}}(0.05 \mathrm{mmol})$ instead of the preformed $\mathrm{Zn}$ complex. The reactor was sealed and maintained at the working temperature, with constant stirring (600 rpm) in a thermostated bath for the duration of the reaction. Upon completion the resulting mixture was evaporated to dryness affording a residue that was extracted with dichloromethane $(10 \mathrm{~mL})$ and then filtered with a $0.45 \mu \mathrm{m}$ nylon syringe filter. An aliquot $(1 \mathrm{~mL})$ of the resulting solution was evaporated to dryness and then the residue was analyzed by ${ }^{1} \mathrm{H}$ and ${ }^{31} \mathrm{P}\left\{{ }^{1} \mathrm{H}\right\}$ NMR. Finally, an aliquot (1 mL) of the dichloromethane solution was analyzed by HPLC (by diluting with $10 \mathrm{~mL}$ of isopropanol).

\section{Results and discussion}

\section{Syntheses of complexes 1-8}

The treatment of solutions of zinc acetate or copper acetate with $\mathrm{HL}^{\mathrm{R}}$ compounds results in the formation, after the appropriate work up, of colourless or blue crystals of compounds 1-4 (Zn) or 5-8 (Cu), respectively (Scheme 2). Broad IR bands centred at around $1640 \mathrm{~cm}^{-1}$, due to the antisymmetric $\mathrm{COO}$ vibrations, are indicative of the presence of carboxylate groups in these complexes. These bands are slightly shifted to lower wavenumbers with respect to those of the $\mathrm{HL}^{\mathrm{R}}$ compounds (for instance, $1684 \mathrm{~cm}^{-1}$ for compound $\mathrm{HL}^{\mathrm{iPr}}$ ), in agreement with ligand $\left[\mathrm{L}^{\mathrm{R}}\right]^{-}$coordination. A comparable absorption was reported for the analogous zinc derivatives with the $\left[\mathrm{L}^{\mathrm{H}}\right]^{-}$and $\left[\mathrm{L}^{\mathrm{Me}}\right]^{-}$ligands ${ }^{7 a, c, 16}$ or for copper compounds with the $\left[\mathrm{L}^{\mathrm{H}}\right]^{-}$ ligand. ${ }^{8}$ The attribution of the absorptions within the range $1390-1370 \mathrm{~cm}^{-1}$ to the symmetric COO vibrations allowed the determination of a $\Delta\left(\nu \mathrm{COO}_{\text {asym }}-\nu \mathrm{COO}_{\text {sym }}\right)$ value of $c a .250 \mathrm{~cm}^{-1}$. This value is compatible with the $\mathrm{K}^{1}-\mathrm{O}$ coordination of the carboxylate group observed in the structural characterization of these compounds (see below). The NMR spectra $\left({ }^{1} \mathrm{H}\right.$ and $\left.{ }^{13} \mathrm{C}\left\{{ }^{1} \mathrm{H}\right\}\right)$ for complexes $\mathbf{2 - 4}$ are similar to those

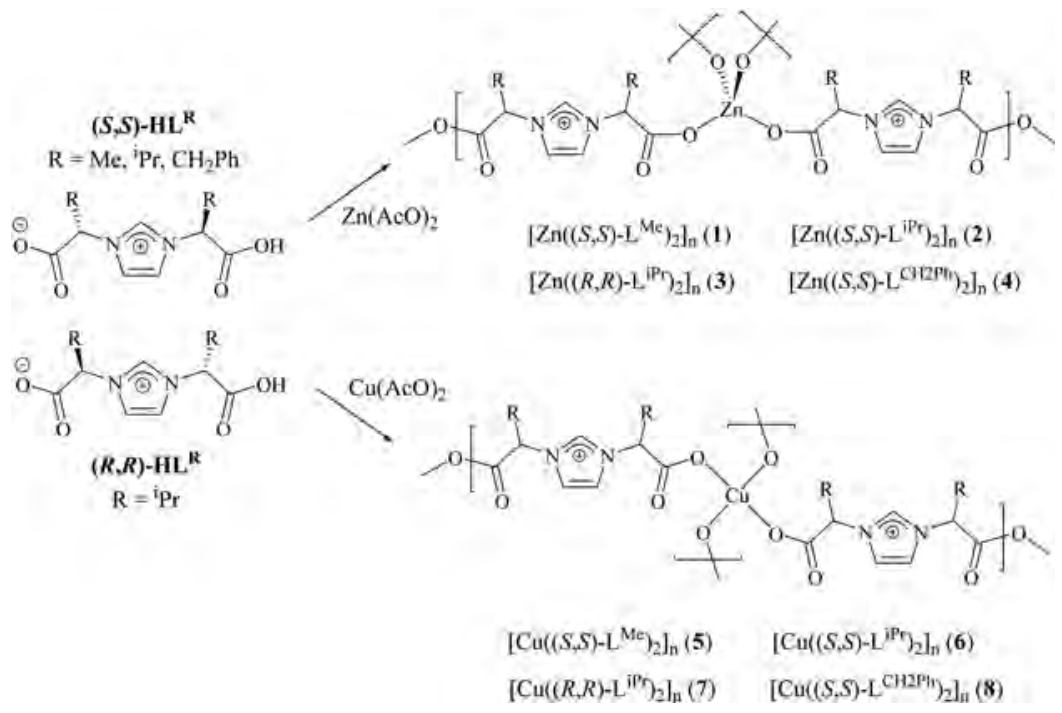

Scheme 2 Synthesis of zinc (1-4) and copper (5-8) complexes. 
reported for $\mathrm{HL}^{\mathrm{R}}$ compounds ${ }^{13}$ and only small displacements of the $\left[\mathrm{L}^{\mathrm{R}}\right]^{-}$signals are observed with respect to the parent $\mathrm{HL}^{\mathrm{R}}$ compounds. The spectroscopic properties of complex $\mathbf{1}$, IR and NMR spectra, are similar to those reported in the bibliography. ${ }^{16}$ Compounds 5-8 are paramagnetic and the $\mu_{\text {eff }}$ values, close to $1.7 \mu_{\mathrm{B}}$, are in agreement with the presence of a square planar copper(II) centre. To our knowledge, there are no structurally characterised examples of d-metal compounds with the chiral ligands $\left[\mathrm{L}^{\mathrm{iPr}}\right]^{-}$and $\left[\mathrm{L}^{\mathrm{CH}_{2} \mathrm{Ph}}\right]^{-}$and, in order to establish the crystal structures of these complexes, singlecrystal X-ray diffraction studies were carried out with complexes 2, 4, 6 and 8. Additionally, complex 5 ([L $\left.\mathrm{L}^{\mathrm{Me}}\right]^{-}$ligand) was also structurally characterised by single-crystal X-ray methods. Characterization by X-ray powder diffraction, XRPD, was performed with complexes $\mathbf{1}, \mathbf{3}$ and 7.

\section{Structural characterization of zinc complexes}

Compounds 2 and 4 crystallise in the $P 2{ }_{1} 2_{1} 2_{1}$ space group, orthorhombic, and in the $P 3_{2}$ space group, trigonal, respectively, and both are two-dimensional coordination polymers in which the zinc ions are interconnected by bridging $\left[\mathrm{L}^{\mathrm{R}}\right]^{-}(\mathrm{R}=$ $\left.{ }^{\mathrm{i}} \mathrm{Pr}, 2 ; \mathrm{CH}_{2} \mathrm{Ph}, 4\right)$ anions through the carboxylate groups. The selected structural parameters of 2 and 4 are collected in Table 1 . Both carboxylate groups are $\kappa^{1}$-coordinated and this monodentate bonding mode is consequent with the asymmetry observed between the two $\mathrm{C}-\mathrm{O}$ distances of the carboxylate moieties (compare, for instance in 2 , the observed ranges of
1.18-1.24 and 1.26-1.29 $\AA$ for the $\mathrm{C}=\mathrm{O}$ and $\mathrm{C}-\mathrm{O}$ bonds, respectively). This $\mu-\kappa^{1}, \kappa^{1}$-coordination mode was also observed in the related zinc derivatives with the non-chiral $\left[\mathrm{L}^{\mathrm{H}}\right]^{-}$and chiral $\left[\mathrm{L}^{\mathrm{Me}}\right]^{-}$anions. ${ }^{7 a, c, 16}$ The coordination geometry of zinc is tetrahedral in $\mathbf{2}$ and $\mathbf{4}$, with values for the fourcoordinate geometry index ${ }^{30} \tau_{4}$ of 0.9 and 0.8 , respectively. The $\mathrm{Zn}-\mathrm{O}$ distances found in the four $\kappa^{1}$-carboxylate moieties are within the range 1.93-1.99 $\AA$, in agreement with the experimental lengths observed for other zinc carboxylates (Cambridge Structural Database search $^{31}$ ). The asymmetric unit of 2 (Fig. 1a) consists of two zinc ions and four $\left[\mathrm{L}^{\mathrm{iPr}}\right]^{-}$ anions, in agreement with the composition $\mathrm{Zn}: 2 \mathrm{~L}^{\mathrm{iPr}}$, analytically determined. The relative orientation of the 3-methylbutanoate arms with respect to the imidazolium ring is dissimilar within the asymmetric unit. Only one $\mathrm{L}^{\mathrm{iPr}}$ ligand shows a roughly cis disposition of the carboxylate groups (torsion angle $\mathrm{C}_{\text {carboxy }}-\mathrm{C}_{\text {chiral }}-\mathrm{C}_{\text {chiral }}^{\prime}-\mathrm{C}_{\text {carboxy }}^{\prime}$ of $\mathrm{ca}$. $50^{\circ}$ ). The three remaining $\left[\mathrm{L}^{\mathrm{iPr}}\right]^{-}$ligands display these torsion angles close to $c a .85^{\circ}$. This feature is responsible of the construction of the two-dimensional polymer (Fig. 2b). This 2D distribution found in 2 differs from that observed in the structure of the related complex $\left[\mathrm{Zn}\left(\mathrm{L}^{\mathrm{Me}}\right)_{2}\right]_{n},{ }^{16}$ in which there are two relative orientations of the dicarboxylate arms within the asymmetric unit with $\mathrm{C}_{\text {carboxy }}-\mathrm{C}_{\text {chiral }}-\mathrm{C}_{\text {chiral }}^{\prime}-\mathrm{C}_{\text {carboxy }}^{\prime}$ torsion angles around $70^{\circ}$ and $175^{\circ}$ (trans disposition). The asymmetric unit of 4 (Fig. 2a) consists of one zinc ion and two $\left[\mathrm{L}^{\mathrm{CH}_{2} \mathrm{Ph}}\right]^{-}$anions and the relative orientation of the 3-phenylpropanoate arms with respect

Table 1 Selected structural parameters for zinc complexes 2 and 4

\begin{tabular}{|c|c|c|c|c|c|c|}
\hline Distances $(\AA)$ & 2 & & & & 4 & \\
\hline \multirow[t]{4}{*}{$\mathrm{Zn}-\mathrm{O}$} & $\mathrm{Zn}(1)-\mathrm{O}(1)$ & $1.945(7)$ & $\mathrm{Zn}(2)-\mathrm{O}(9)$ & $1.992(7)$ & $\mathrm{Zn}(1)-\mathrm{O}(5)$ & $1.934(4)$ \\
\hline & $\mathrm{Zn}(1)-\mathrm{O}(3)$ & $1.966(7)$ & $\mathrm{Zn}(2)-\mathrm{O}(11)$ & $1.962(7)$ & $\mathrm{Zn}(1)-\mathrm{O}(7)$ & $1.939(4)$ \\
\hline & $\mathrm{Zn}(1)-\mathrm{O}(5)$ & $1.967(7)$ & $\mathrm{Zn}(2)-\mathrm{O}(13)$ & $1.935(7)$ & $\mathrm{Zn}(1)-\mathrm{O}(3)$ & $1.958(4)$ \\
\hline & $\mathrm{Zn}(1)-\mathrm{O}(7)$ & $1.987(7)$ & $\mathrm{Zn}(2)-\mathrm{O}(15)$ & $1.938(7)$ & $\mathrm{Zn}(1)-\mathrm{O}(1)$ & $1.963(4)$ \\
\hline \multirow[t]{8}{*}{$\mathrm{C}-\mathrm{O}$} & $\mathrm{O}(1)-\mathrm{C}(12)$ & $1.284(11)$ & $\mathrm{O}(9)-\mathrm{C}(24)$ & $1.265(13)$ & $\mathrm{O}(1)-\mathrm{C}(1)$ & $1.250(6)$ \\
\hline & $\mathrm{O}(2)-\mathrm{C}(12)$ & $1.233(12)$ & $\mathrm{O}(10)-\mathrm{C}(24)$ & $1.242(12)$ & $\mathrm{O}(2)-\mathrm{C}(1)$ & $1.227(6)$ \\
\hline & $\mathrm{O}(3)-\mathrm{C}(13)$ & $1.289(14)$ & $\mathrm{O}(11)-\mathrm{C}(44)$ & $1.272(13)$ & $\mathrm{O}(3)-\mathrm{C}(21)$ & $1.240(6)$ \\
\hline & $\mathrm{O}(4)-\mathrm{C}(13)$ & $1.200(14)$ & $\mathrm{O}(12)-\mathrm{C}(44)$ & $1.233(14)$ & $\mathrm{O}(4)-\mathrm{C}(21)$ & $1.217(7)$ \\
\hline & $\mathrm{O}(5)-\mathrm{C}(14)$ & $1.253(14)$ & $\mathrm{O}(13)-\mathrm{C}(48)$ & $1.283(13)$ & $\mathrm{O}(5)-\mathrm{C}(30)$ & $1.272(7)$ \\
\hline & $\mathrm{O}(6)-\mathrm{C}(14)$ & $1.229(15)$ & $\mathrm{O}(14)-\mathrm{C}(48)$ & $1.232(13)$ & $\mathrm{O}(6)-\mathrm{C}(30)$ & $1.219(7)$ \\
\hline & $\mathrm{O}(7)-\mathrm{C}(19)$ & $1.288(13)$ & $\mathrm{O}(15)-\mathrm{C}(32)$ & $1.293(12)$ & $\mathrm{O}(7)-\mathrm{C}(42)$ & $1.277(7)$ \\
\hline & $\mathrm{O}(8)-\mathrm{C}(19)$ & $1.214(13)$ & $\mathrm{O}(16)-\mathrm{C}(32)$ & $1.219(13)$ & $\mathrm{O}(8)-\mathrm{C}(42)$ & $1.219(7)$ \\
\hline \multicolumn{7}{|l|}{ Angles (०) } \\
\hline \multirow[t]{6}{*}{$\mathrm{O}-\mathrm{Zn}-\mathrm{O}$} & $\mathrm{O}(1)-\mathrm{Zn}(1)-\mathrm{O}(3)$ & $119.2(3)$ & $\mathrm{O}(15)-\mathrm{Zn}(2)-\mathrm{O}(13)$ & $119.2(3)$ & $\mathrm{O}(5)-\mathrm{Zn}(1)-\mathrm{O}(7)$ & $108.37(17)$ \\
\hline & $\mathrm{O}(1)-\mathrm{Zn}(1)-\mathrm{O}(5)$ & $108.7(3)$ & $\mathrm{O}(15)-\mathrm{Zn}(2)-\mathrm{O}(11)$ & $111.0(3)$ & $\mathrm{O}(5)-\mathrm{Zn}(1)-\mathrm{O}(3)$ & $107.1(2)$ \\
\hline & $\mathrm{O}(3)-\mathrm{Zn}(1)-\mathrm{O}(5)$ & $115.7(3)$ & $\mathrm{O}(13)-\mathrm{Zn}(2)-\mathrm{O}(11)$ & $110.8(3)$ & $\mathrm{O}(7)-\mathrm{Zn}(1)-\mathrm{O}(3)$ & $121.9(2)$ \\
\hline & $\mathrm{O}(1)-\mathrm{Zn}(1)-\mathrm{O}(7)$ & $96.9(3)$ & $\mathrm{O}(15)-\mathrm{Zn}(2)-\mathrm{O}(9)$ & $97.4(3)$ & $\mathrm{O}(5)-\mathrm{Zn}(1)-\mathrm{O}(1)$ & $121.7(2)$ \\
\hline & $\mathrm{O}(3)-\mathrm{Zn}(1)-\mathrm{O}(7)$ & $111.3(3)$ & $\mathrm{O}(13)-\mathrm{Zn}(2)-\mathrm{O}(9)$ & $105.5(3)$ & $\mathrm{O}(7)-\mathrm{Zn}(1)-\mathrm{O}(1)$ & $108.46(19)$ \\
\hline & $\mathrm{O}(5)-\mathrm{Zn}(1)-\mathrm{O}(7)$ & $102.1(3)$ & $\mathrm{O}(11)-\mathrm{Zn}(2)-\mathrm{O}(9)$ & $112.0(3)$ & $\mathrm{O}(3)-\mathrm{Zn}(1)-\mathrm{O}(1)$ & $89.23(15)$ \\
\hline \multirow[t]{4}{*}{$\mathrm{C}-\mathrm{O}-\mathrm{Zn}$} & $\mathrm{C}(12)-\mathrm{O}(1)-\mathrm{Zn}(1)$ & $118.7(6)$ & $\mathrm{C}(24)-\mathrm{O}(9)-\mathrm{Zn}(2)$ & $120.7(6)$ & $\mathrm{C}(1)-\mathrm{O}(1)-\mathrm{Zn}(1)$ & $140.8(4)$ \\
\hline & $\mathrm{C}(13)-\mathrm{O}(3)-\mathrm{Zn}(1)$ & $114.1(7)$ & $\mathrm{C}(44)-\mathrm{O}(11)-\mathrm{Zn}(2)$ & $122.8(7)$ & $\mathrm{C}(21)-\mathrm{O}(3)-\mathrm{Zn}(1)$ & $143.3(4)$ \\
\hline & $\mathrm{C}(14)-\mathrm{O}(5)-\mathrm{Zn}(1)$ & $121.5(7)$ & $\mathrm{C}(48)-\mathrm{O}(13)-\mathrm{Zn}(2)$ & $115.8(7)$ & $\mathrm{C}(30)-\mathrm{O}(5)-\mathrm{Zn}(1)$ & $116.2(4)$ \\
\hline & $\mathrm{C}(19)-\mathrm{O}(7)-\mathrm{Zn}(1)$ & $114.4(7)$ & $\mathrm{C}(32)-\mathrm{O}(15)-\mathrm{Zn}(2)$ & $128.8(7)$ & $\mathrm{C}(42)-\mathrm{O}(7)-\mathrm{Zn}(1)$ & $115.4(4)$ \\
\hline \multirow[t]{4}{*}{$\mathrm{O}-\mathrm{C}-\mathrm{O}$} & $\mathrm{O}(2)-\mathrm{C}(12)-\mathrm{O}(1)$ & $126.9(10)$ & $\mathrm{O}(10)-\mathrm{C}(24)-\mathrm{O}(9)$ & $127.8(10)$ & $\mathrm{O}(2)-\mathrm{C}(1)-\mathrm{O}(1)$ & $123.4(4)$ \\
\hline & $\mathrm{O}(2)-\mathrm{C}(12)-\mathrm{C}(8)$ & $118.8(8)$ & $\mathrm{O}(16)-\mathrm{C}(32)-\mathrm{O}(15)$ & $126.9(9)$ & $\mathrm{O}(4)-\mathrm{C}(21)-\mathrm{O}(3)$ & $123.2(5)$ \\
\hline & $\mathrm{O}(4)-\mathrm{C}(13)-\mathrm{O}(3)$ & $126.9(10)$ & $\mathrm{O}(12)-\mathrm{C}(44)-\mathrm{O}(11)$ & $126.6(11)$ & $\mathrm{O}(6)-\mathrm{C}(30)-\mathrm{O}(5)$ & $126.6(5)$ \\
\hline & $\mathrm{O}(6)-\mathrm{C}(14)-\mathrm{O}(5)$ & $127.1(11)$ & $\mathrm{O}(14)-\mathrm{C}(48)-\mathrm{O}(13)$ & $126.7(9)$ & $\mathrm{O}(8)-\mathrm{C}(42)-\mathrm{O}(7)$ & $126.4(6)$ \\
\hline
\end{tabular}

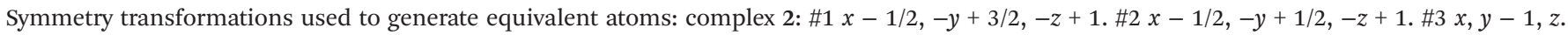
$\# 4 x+1 / 2,-y+1 / 2,-z+1$. \#5 $x, y+1, z$. \#6 $x+1 / 2,-y+3 / 2,-z+1$. Complex 4: \#1 $x-1, y, z ; \# 2 x-1, y-1, z ; \# 3 x+1, y, z ; \# 4 x+1, y+1, z$. 

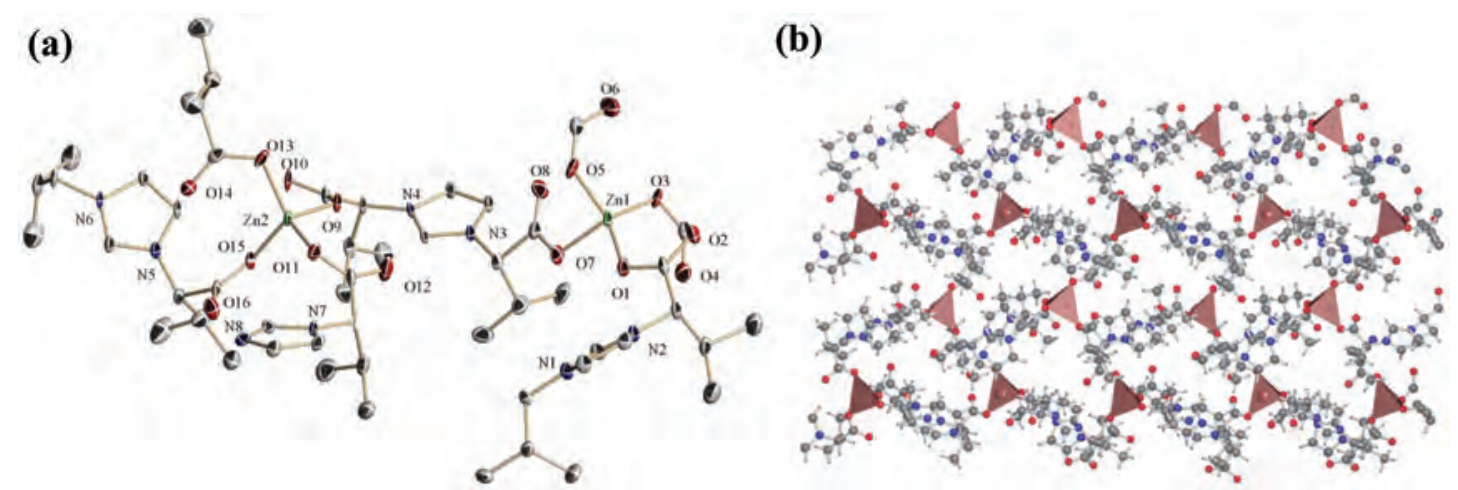

Fig. 1 (a) Asymmetric unit of compound 2, hydrogen atoms are omitted for clarity. (b) Lamellar sheet in 2 viewed along the $c$ axis with a tetrahedral polyhedron for zinc atoms.

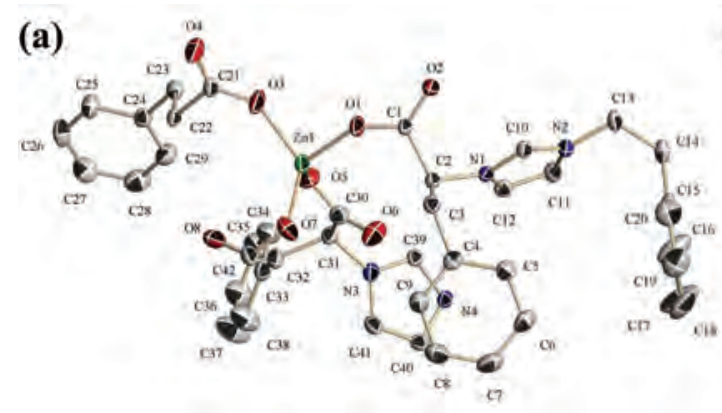

(b)

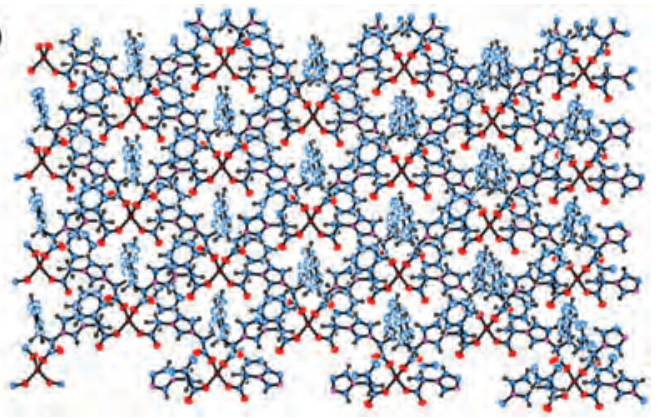

Fig. 2 (a) Asymmetric unit of compound 4, hydrogen atoms and solvent crystallization molecules are omitted for clarity. (b) 2D sheet in 4 viewed along the $c$ axis.

to the imidazolium ring is roughly cis with torsion angles $\mathrm{C}_{\text {carboxy }}-\mathrm{C}_{\text {chiral }}-\mathrm{C}_{\text {chiral }}^{\prime}-\mathrm{C}_{\text {carboxy }}^{\prime}$ close to $20^{\circ}$. The resulting $2 \mathrm{D}$ coordination polymer is slightly different from that of complex 2 (Fig. 2b). In both complexes, 2 and 4, the 3D crystal distribution was produced by the packing of the $2 \mathrm{D}$ lamellar sheets due to non-covalent interactions through the alkyl hydrophobic part of the $\left[\mathrm{L}^{\mathrm{R}}\right]^{-}$anions (see, for example, Fig. S1 for 2 in the ESI†).

Concerning complexes 1 and 3, they were characterised by XRPD methods. The experimental X-ray diffractogram of $\mathbf{1}$ shows no significant differences with respect to the simulated powder diffraction pattern calculated from the single-crystal data previously reported (refcode VITHUD ${ }^{16}$ ) and no further comments are required. Rietveld refinement from the XRPD of complex $\mathbf{3}$ was performed and its final Rietveld plot is given in Fig. S2. $\dagger$ From these results, we deduced that the overall structure of complex 3 is completely similar to that of its enantiomer 2 (both showed identical XRPDs, Fig. S3†), which was previously solved by single crystal X-ray methods.

\section{Structural characterization of copper complexes}

Complexes 5 and 6 crystallise in the $P_{1}$ space group, triclinic, while 8 crystallises in the $C 222_{1}$ space group, orthorhombic. All are two-dimensional coordination polymers in which the copper ions are bridged by monodentate carboxylate groups of
$\mathrm{L}^{\mathrm{R}}$ anions. The selected structural parameters of $\mathbf{5}, \mathbf{6}$ and $\mathbf{8}$ are collected in Table 2. The environment of copper in the three compounds is square planar with values lower than 0.1 for the four-coordinate geometry index $\tau_{4}$. In these compounds, the $\mathrm{Cu}-\mathrm{O}$ bonding distances are within the range $1.92-2.00 \AA$, in agreement with the experimental lengths observed for other copper carboxylates. ${ }^{31}$ The distances between copper and the second oxygen atom of the carboxylate group cover the range 2.58-2.76 A. Although these distances are slightly lower than the sum of the van der Waals radii, they were essentially considered as non-bonding distances (mean value for the $\mathrm{Cu}-\mathrm{O}$ bond length in $\mathrm{Cu}\left(\kappa^{1}-\mathrm{OC}(\mathrm{O})-\mathrm{R}\right)$ complexes is 2.01(2) $\AA$ (ref. 31)). The asymmetric unit of complex 5 shows two nonsymmetry related copper atoms, $\mathrm{Cu} 1$ and $\mathrm{Cu} 2$, that originate from two different $\mathrm{Cu}-\mathrm{L}^{\mathrm{Me}}$ polymers with $\mathrm{C}_{\text {carboxy }}-\mathrm{C}_{\text {chiral }^{-}}$ $\mathrm{C}_{\text {chiral }}^{\prime} \mathrm{C}^{\prime}$ carboxy torsion angles of $c a .55$ and $41^{\circ}$, more in agreement with a roughly cis disposition of the CHMeCOO groups with respect to the imidazolium ring. Fig. 3a shows the common $\mu^{2}-\kappa^{1}-\mathrm{O}^{1}, \kappa^{1}-\mathrm{O}^{3}$ coordination mode found for the bridging $\left[\mathrm{L}^{\mathrm{Me}}\right]^{-}$anion in both $\mathrm{Cu} 1$ and $\mathrm{Cu} 2$ atoms, while the resulting $2 \mathrm{D}$ disposition along the $c$ axis is depicted in Fig. 3b. This 2D structure is formed by the accommodation of the two different $\mathrm{Cu}-\mathrm{L}^{\mathrm{Me}}$ polymers of $\mathrm{Cu} 1$ and $\mathrm{Cu} 2$ atoms, which are illustrated in Fig. 3c. These two different $\mathrm{Cu}-\mathrm{L}^{\mathrm{Me}}$ polymers are connected by weak $\mathrm{C}-\mathrm{H} \cdots \mathrm{O}$ non-classical hydrogen bonds 
Table 2 Selected structural parameters for copper complexes 5, 6 and 8

\begin{tabular}{|c|c|c|c|c|c|c|c|c|}
\hline Distances $(\AA)$ & 5 & & 6 & & 8 & & & \\
\hline & $\mathrm{Cu}(1)-\mathrm{O}(3)$ & $1.9736(16)$ & $\mathrm{Cu}(1)-\mathrm{O}(3)$ & $1.948(7)$ & $\mathrm{Cu}(1)-\mathrm{O}(9)$ & $1.941(4)$ & $\mathrm{Cu}(2)-\mathrm{O}(7)$ & $1.945(4)$ \\
\hline & $\mathrm{Cu}(2)-\mathrm{O}(7)$ & $2.0073(14)$ & $\mathrm{Cu}(1)-\mathrm{O}(7)$ & $1.924(7)$ & & & & \\
\hline \multirow[t]{6}{*}{$\mathrm{C}-\mathrm{O}$} & $\mathrm{O}(1)-\mathrm{C}(5)$ & $1.267(3)$ & $\mathrm{O}(1)-\mathrm{C}(9)$ & $1.296(12)$ & $\mathrm{O}(1)-\mathrm{C}(1 \mathrm{~B})$ & $1.161(15)$ & $\mathrm{O}(8)-\mathrm{C}(34)$ & $1.217(7)$ \\
\hline & $\mathrm{O}(2)-\mathrm{C}(5)$ & $1.218(3)$ & $\mathrm{O}(2)-\mathrm{C}(9)$ & $1.229(12)$ & $\mathrm{O}(1)-\mathrm{C}(1 \mathrm{~A})$ & $1.303(13)$ & $\mathrm{O}(9)-\mathrm{C}(43)$ & $1.235(8)$ \\
\hline & $\mathrm{O}(3)-\mathrm{C}(9)$ & $1.283(2)$ & $\mathrm{O}(3)-\mathrm{C}(20)$ & $1.261(12)$ & $\mathrm{O}(3)-\mathrm{C}(13)$ & $1.285(7)$ & $\mathrm{O}(10)-\mathrm{C}(43)$ & $1.241(8)$ \\
\hline & $\mathrm{O}(6)-\mathrm{C}(14)$ & $1.225(3)$ & $\mathrm{O}(6)-\mathrm{C}(25)$ & $1.231(12)$ & $\mathrm{O}(6)-\mathrm{C}(22)$ & $1.229(7)$ & $\mathrm{C}(1 \mathrm{~A})-\mathrm{O}(2 \mathrm{~A})$ & $1.229(14)$ \\
\hline & $\mathrm{O}(7)-\mathrm{C}(16)$ & $1.275(2)$ & $\mathrm{O}(7)-\mathrm{C}(26)$ & $1.279(13)$ & $\mathrm{O}(7)-\mathrm{C}(34)$ & $1.272(7)$ & $\mathrm{C}(1 \mathrm{~B})-\mathrm{O}(2 \mathrm{~B})$ & $1.236(16)$ \\
\hline & $\mathrm{O}(8)-\mathrm{C}(16)$ & $1.229(2)$ & $\mathrm{O}(8)-\mathrm{C}(26)$ & $1.239(12)$ & & & & \\
\hline \multicolumn{9}{|l|}{ Angles ( ${ }^{\circ}$ ) } \\
\hline \multirow[t]{3}{*}{$\mathrm{O}-\mathrm{Cu}-\mathrm{O}$} & $\mathrm{O}(1)-\mathrm{Cu}(1)-\mathrm{O}(1) \# 1$ & $84.56(13)$ & $\mathrm{O}(7)-\mathrm{Cu}(1)-\mathrm{O}(1)$ & $89.4(3)$ & $\mathrm{O}(1)-\mathrm{Cu}(1)-\mathrm{O}(9)$ & 92.45(19) & $\mathrm{O}(7) \# 4-\mathrm{Cu}(2)-\mathrm{O}(7)$ & $89.1(2)$ \\
\hline & $\mathrm{O}(1)-\mathrm{Cu}(1)-\mathrm{O}(3)$ & $92.67(8)$ & $\mathrm{O}(7)-\mathrm{Cu}(1)-\mathrm{O}(3)$ & $176.3(4)$ & $\mathrm{O}(1)-\mathrm{Cu}(1)-\mathrm{O}(11) \# 1$ & $90.3(2)$ & $\mathrm{O}(7) \# 4-\mathrm{Cu}(2)-\mathrm{O}(3) \# 3$ & $91.24(17)$ \\
\hline & $\mathrm{O}(7) \# 3-\mathrm{Cu}(2)-\mathrm{O}(7)$ & $83.92(8)$ & & & & & & \\
\hline \multirow[t]{4}{*}{$\mathrm{C}-\mathrm{O}-\mathrm{Cu}$} & $\mathrm{C}(5)-\mathrm{O}(1)-\mathrm{Cu}(1)$ & $123.03(15)$ & $\mathrm{C}(9)-\mathrm{O}(1)-\mathrm{Cu}(1)$ & $121.7(6)$ & $\mathrm{C}(1 \mathrm{~B})-\mathrm{O}(1)-\mathrm{Cu}(1)$ & $123.4(8)$ & $\mathrm{C}(34)-\mathrm{O}(7)-\mathrm{Cu}(2)$ & 115.5(4) \\
\hline & $\mathrm{C}(9)-\mathrm{O}(3)-\mathrm{Cu}(1)$ & $102.57(13)$ & $\mathrm{C}(20)-\mathrm{O}(3)-\mathrm{Cu}(1)$ & $106.7(6)$ & $\mathrm{C}(1 \mathrm{~A})-\mathrm{O}(1)-\mathrm{Cu}(1)$ & 117.1(6) & $\mathrm{C}(43)-\mathrm{O}(9)-\mathrm{Cu}(1)$ & $118.1(4)$ \\
\hline & $\mathrm{C}(14)-\mathrm{O}(5)-\mathrm{Cu}(2)$ & $114.73(13)$ & $\mathrm{C}(25)-\mathrm{O}(5)-\mathrm{Cu}(1)$ & 108.7(5) & $\mathrm{C}(13)-\mathrm{O}(3)-\mathrm{Cu}(2) \# 5$ & 108.3(4) & $\mathrm{C}(55)-\mathrm{O}(11)-\mathrm{Cu}(1) \# 2$ & $105.7(4)$ \\
\hline & $\mathrm{C}(16)-\mathrm{O}(7)-\mathrm{Cu}(2)$ & $102.95(13)$ & $\mathrm{C}(26)-\mathrm{O}(7)-\mathrm{Cu}(1)$ & $125.1(5)$ & $\mathrm{C}(22)-\mathrm{O}(5)-\mathrm{Cu}(1)$ & $107.3(3)$ & & \\
\hline \multirow[t]{4}{*}{$\mathrm{O}-\mathrm{C}-\mathrm{O}$} & $\mathrm{O}(2)-\mathrm{C}(5)-\mathrm{O}(1)$ & $127.7(2)$ & $\mathrm{O}(2)-\mathrm{C}(9)-\mathrm{O}(1)$ & $124.6(7)$ & $\mathrm{O}(2 \mathrm{~A})-\mathrm{C}(1 \mathrm{~A})-\mathrm{O}(1)$ & $124.6(10)$ & $\mathrm{O}(8)-\mathrm{C}(34)-\mathrm{O}(7)$ & $126.8(5)$ \\
\hline & $\mathrm{O}(4)-\mathrm{C}(9)-\mathrm{O}(3)$ & $124.6(2)$ & $\mathrm{O}(4)-\mathrm{C}(20)-\mathrm{O}(3)$ & $125.2(8)$ & $\mathrm{O}(1)-\mathrm{C}(1 \mathrm{~B})-\mathrm{O}(2 \mathrm{~B})$ & $120.3(13)$ & $\mathrm{O}(9)-\mathrm{C}(43)-\mathrm{O}(10)$ & 124.1(6) \\
\hline & $\mathrm{O}(6)-\mathrm{C}(14)-\mathrm{O}(5)$ & $126.1(2)$ & $\mathrm{O}(6)-\mathrm{C}(25)-\mathrm{O}(5)$ & $126.0(8)$ & $\mathrm{O}(4)-\mathrm{C}(13)-\mathrm{O}(3)$ & $124.4(5)$ & $\mathrm{O}(12)-\mathrm{C}(55)-\mathrm{O}(11)$ & $126.1(5)$ \\
\hline & $\mathrm{O}(8)-\mathrm{C}(16)-\mathrm{O}(7)$ & $125.1(2)$ & $\mathrm{O}(8)-\mathrm{C}(26)-\mathrm{O}(7)$ & $123.9(9)$ & $\mathrm{O}(6)-\mathrm{C}(22)-\mathrm{O}(5)$ & $124.9(5)$ & & \\
\hline
\end{tabular}

Symmetry transformations used to generate equivalent atoms: complex 5: \#1 -x+2,-y,z. \#2 $x-1 / 2,-y+1 / 2,-z$. \#3 -x+1, $-y, z$. \#4 -x+3/2, $y+1 / 2,-z+1$. \#5 $x+1 / 2,-y+1 / 2,-z$. \#6 -x+3/2,y-1/2, $-z+1$. Complex 6: \#1 $x, y+1, z$. \#2 $x, y, z+1$. \#3 x,y-1, z. \#4 x, y, $z-1$. Complex 8: $\# 1 x+1 / 2,-y+1 / 2,-z+1$. \#2 $x-1 / 2,-y+1 / 2,-z+1$. \#3 $x-1 / 2, y-1 / 2, z$. \#4 $x,-y,-z+1$. \#5 $x+1 / 2, y+1 / 2, z$.

between both the $\mathrm{C}_{\text {chiral }}-\mathrm{H}$ and $\mathrm{C}^{2}{ }_{\text {imidazol }}-\mathrm{H}$ bonds of the bridging $\left[\mathrm{L}^{\mathrm{Me}}\right]^{-}$fragments, belonging to one polymer, and the oxygen atoms of the carboxylate moiety of the $\left[\mathrm{L}^{\mathrm{Me}}\right]^{-}$ligands corresponding to the adjacent polymer.

The relative orientation of the 3-methylbutanoate arms with respect to the imidazolium ring is approximately trans in complex 6, with torsion angles $\mathrm{C}_{\text {carboxy }}-\mathrm{C}_{\text {chiral }}-\mathrm{C}_{\text {chiral }}^{\prime}-\mathrm{C}_{\text {carboxy }}^{\prime}$ of $c a .97$ and $117^{\circ}$. In contrast with the related zinc complex 2, two different $\mu^{2}-\kappa^{1}-\mathrm{O}^{1}, \kappa^{1}-\mathrm{O}^{3}$ coordination modes were found for bridged $\left[\mathrm{L}^{\mathrm{iPr}}\right]^{-}$anions, corresponding to monodentate $\kappa^{1}$-syn, $\kappa^{1}$-syn and $\kappa^{1}$-anti, $\kappa^{1}$-anti coordination (Fig. $4 \mathrm{a}$ ). This variation produces a slightly different 2D sheet of $\mathbf{6}$ in comparison to 2 (Fig. $4 \mathrm{~b}$ ). In $\mathbf{6}$, the 3D packing occurred by non-covalent interactions between the ${ }^{\mathrm{i}} \mathrm{Pr}$ groups of the sheets (Fig. $\mathrm{S} 4 \dagger$ ). Additionally, the supramolecular arrangement is reinforced by the presence of weak $\mathrm{C}-\mathrm{H}$... O non-classical hydrogen bonds between the $\mathrm{C}_{\text {chiral }}-\mathrm{H}$ fragments belonging to one $2 \mathrm{D}$ sheet and carbonyl groups of the carboxylate moiety of the neighbouring sheet. Finally, the general $\mu^{2}-\kappa^{1}-\mathrm{O}^{1}, \kappa^{1}-\mathrm{O}^{3}$ coordination mode is also present in the complex 8. Fig. 5a shows the crystal packing of complex 8 along the $c$ axis. The $\mathrm{C}_{\text {carboxy }}{ }^{-}$ $\mathrm{C}_{\text {chiral }}-\mathrm{C}_{\text {chiral }}^{\prime}-\mathrm{C}_{\text {carboxy }}^{\prime}$ torsion angles are close to $\mathrm{ca} \cdot 40^{\circ}$, in agreement with a roughly cis disposition of the $\mathrm{CH}\left(\mathrm{CH}_{2} \mathrm{Ph}\right)$ COO groups with respect to the imidazolium ring, as occurred in the related zinc complex 4. This disposition generates two- dimensional coordination polymers, which are arranged parallel to the $b$ axis (see Fig. 5b).

Complex 7 was characterised by XRPD methods and showed an identical X-ray diffractogram to that of its enantiomer 6 (Fig. S5 $\dagger$ ). Rietveld refinement was performed and its final Rietveld plot is given in Fig. S6. $\uparrow$ From these results, we deduced that the overall structure of 7 is completely similar to that of its enantiomer 6, solved by single crystal X-ray methods, and no further discussion is required.

\section{TGA study of complexes $2-8$}

With the aim to study the decomposition pathway of these coordination polymers, thermogravimetric analyses were carried out with complexes 2-8 (Fig. 6). TGA analysis of compound 1 was previously reported. ${ }^{16}$ As expected, the enantiomerically related zinc compounds 2 and $3,\left[\mathrm{Zn}\left(\mathrm{L}^{\mathrm{iPr}}\right)_{2} \cdot \mathrm{H}_{2} \mathrm{O}\right]_{n}$, showed identical TGA profiles in which, after the crystallization water loss ( $c a .5 \%$ weight loss), the resulting $\left[\mathrm{Zn}\left(\mathrm{L}^{\mathrm{iPr}}\right)_{2}\right]_{n}$ material was thermally stable up to $c a .280^{\circ} \mathrm{C}$. Then, a simultaneous consecutive decarboxylation and imidazolium decomposition with complete loss of the $\left[\mathrm{L}^{\mathrm{iPr}}\right]^{-}$ligand was observed in the $280-500{ }^{\circ} \mathrm{C}$ range (ca. $85 \%$ weight loss). Complex 4, $\left[\mathrm{Zn}\left((S, S)-\mathrm{L}^{\mathrm{CH}_{2} \mathrm{Ph}}\right)_{2} \cdot 2 \mathrm{DMF} \cdot \mathrm{H}_{2} \mathrm{O}\right]_{n}$, showed a similar TGA profile. A weight loss of about $18 \%$ was observed in the initial stage, at $c a .150{ }^{\circ} \mathrm{C}$, attributable to the loss of the crystal- 


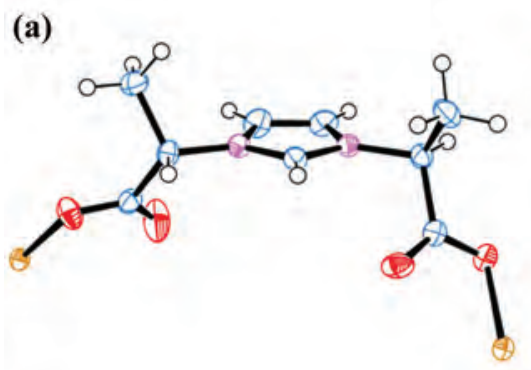

(b)

(c)
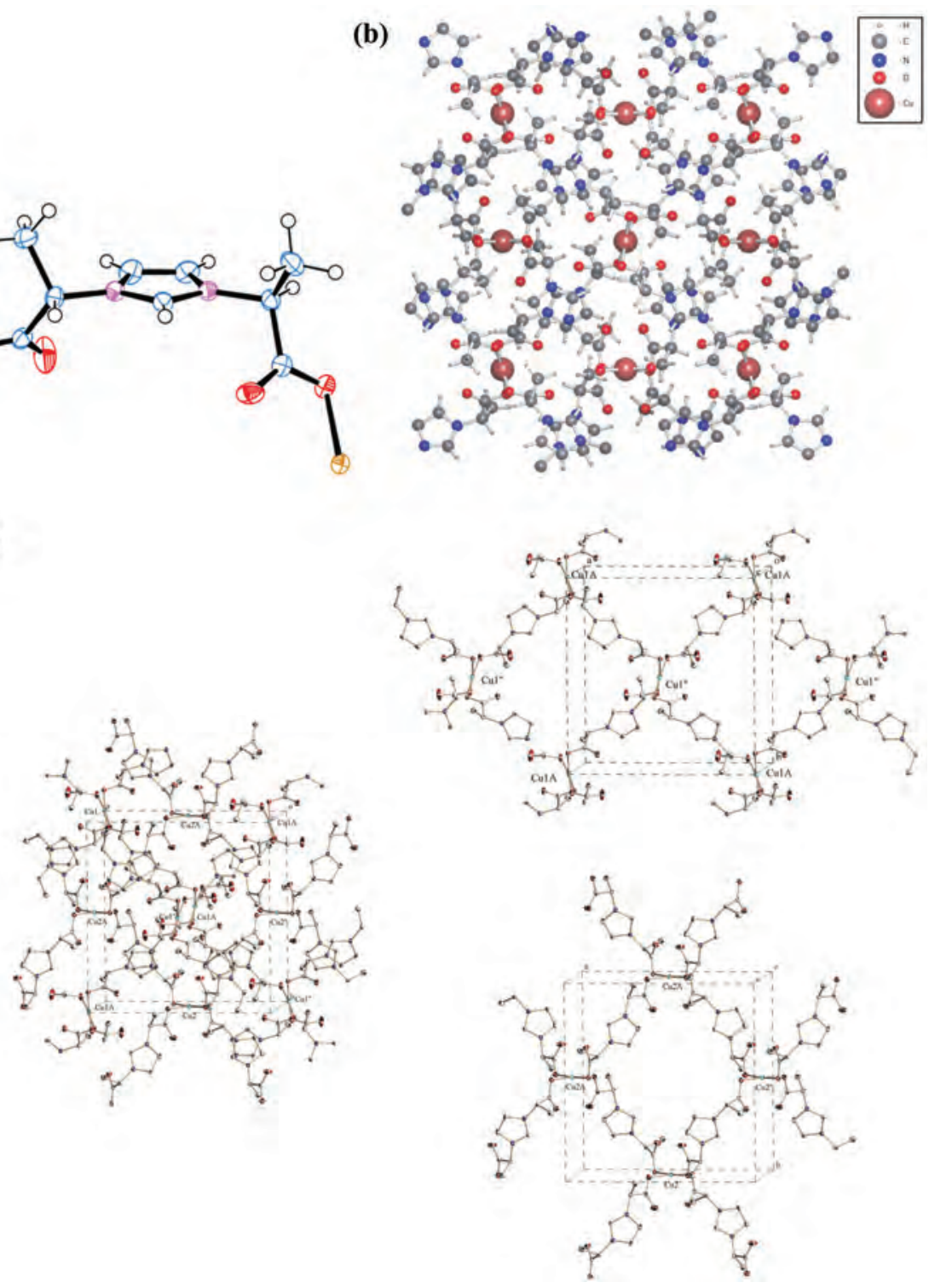

Fig. 3 (a) Common $\mu^{2}-\kappa^{1}-\mathrm{O}^{1}, \kappa^{1}-\mathrm{O}^{3}$ coordination mode of the $\left[\mathrm{L}^{\mathrm{Me}}\right]^{-}$ligand in 5 for the two non-symmetry related copper atoms, Cu1 and Cu2. (b) Lamellar sheet in 5 viewed along the $c$ axis. (c) Crystal packing of 5 (left) and separation of the two different $\mathrm{Cu}-\mathrm{L}^{\mathrm{Me}}$ polymers for Cu1 and Cu2 atoms (right).

lization DMF and water molecules. Subsequently, the elimination of the $\left[\mathrm{L}^{\mathrm{CH}_{2} \mathrm{Ph}}\right]^{-}$ligand by decarboxylation and imidazolium decomposition was completed at $500{ }^{\circ} \mathrm{C}$. There was no weight loss for $\mathbf{2 - 4}$ after $550{ }^{\circ} \mathrm{C}$, and the final product was attributed to the corresponding zinc oxide. The thermogravimetric behavior of compounds $\mathbf{2 - 4}$ is closely connected with that previously reported for the parent $\mathrm{HL}^{\mathrm{R}}$ compounds. In fact, controlled hydrothermal decarboxylation of these $\mathrm{HL}^{\mathrm{R}}$ compounds was proposed as a new approach toward the synthesis of new ionic liquids. ${ }^{3}$ The TGA analysis of copper compounds 5-8 (Fig. 6, bottom) gave analogous results to those discussed for $\mathrm{Zn}$ derivatives. For example, the TGA profile of compound 5, $\left[\mathrm{Cu}\left(\mathrm{L}^{\mathrm{Me}}\right)_{2}\right]_{n}$, was very alike to that reported for complex $\left[\mathrm{Zn}\left(\mathrm{L}^{\mathrm{Me}}\right)_{2}\right]_{n}, \mathbf{1}^{16}$ Complexes 6 and $7,\left[\mathrm{Cu}\left(\mathrm{L}^{\mathrm{iPr}}\right)_{2}\right]_{n}$, were stable until $250{ }^{\circ} \mathrm{C}$ with a decomposition pathway completely similar to that found for their zinc analogues 2 and 3. After a weight loss of about $85 \%\left(550{ }^{\circ} \mathrm{C}\right)$, the resulting material was the corresponding oxide with no additional weight loss after $600{ }^{\circ} \mathrm{C}$. In particular, for the copper complex 6 the formation of the copper oxide, $\mathrm{CuO}$, after heating at $600{ }^{\circ} \mathrm{C}$, was confirmed by PXRD methods (Fig. S7, ESI $\dagger$ ). Finally, for compound $\mathbf{8}$ a stepwise decarboxylation and imidazolium decomposition can be discerned with an inflection point at around $320{ }^{\circ} \mathrm{C}$.

\section{DFT calculations of $\left[\mathrm{L}^{\mathrm{R}}\right]^{-}$anions}

In order to gain further information about the coordination features of the $\left[\mathrm{L}^{\mathrm{R}}\right]^{-}$anions and their conformational flexi- 
(a)

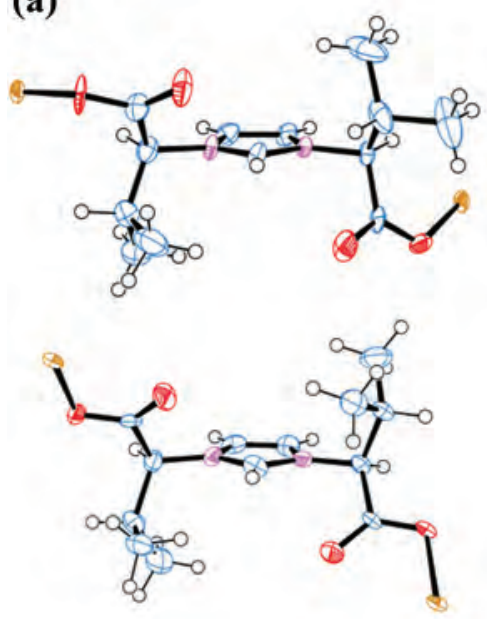

(b)

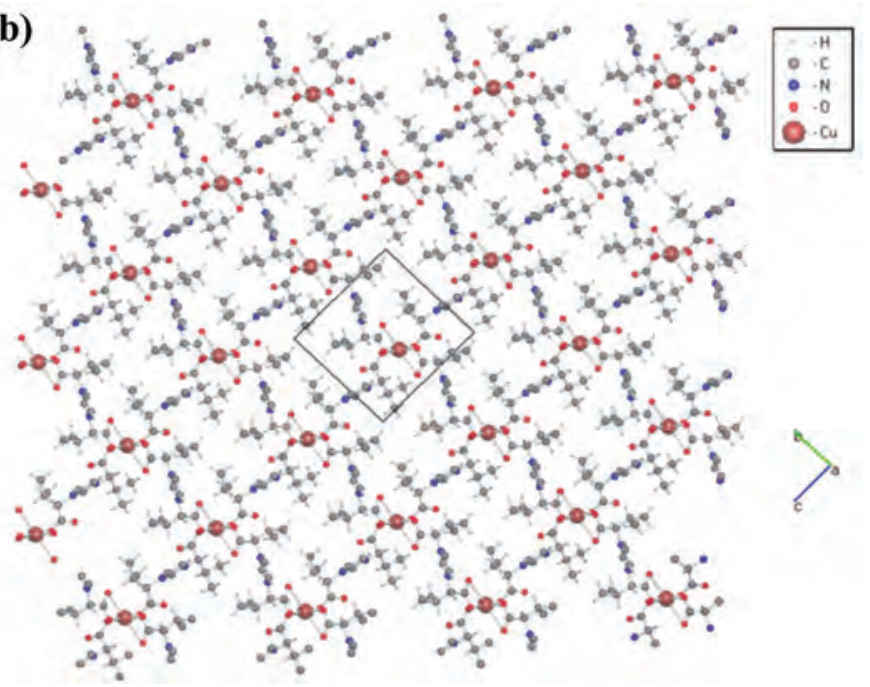

Fig. 4 (a) Two different $\mu^{2}-\kappa^{1}-\mathrm{O}^{1}, \kappa^{1}-\mathrm{O}^{3}$ coordination modes of the $\left[\mathrm{L}^{\mathrm{iPr}}\right]^{-}$ligand in 6 . (b) Lamellar sheet in 6 viewed along the $c$ axis.

(a)

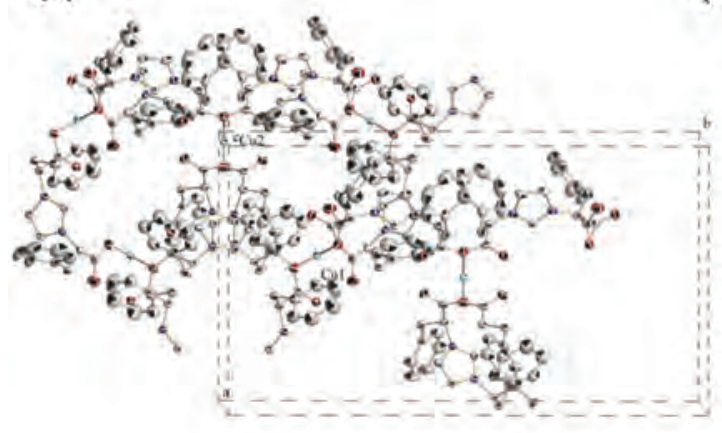

(b)

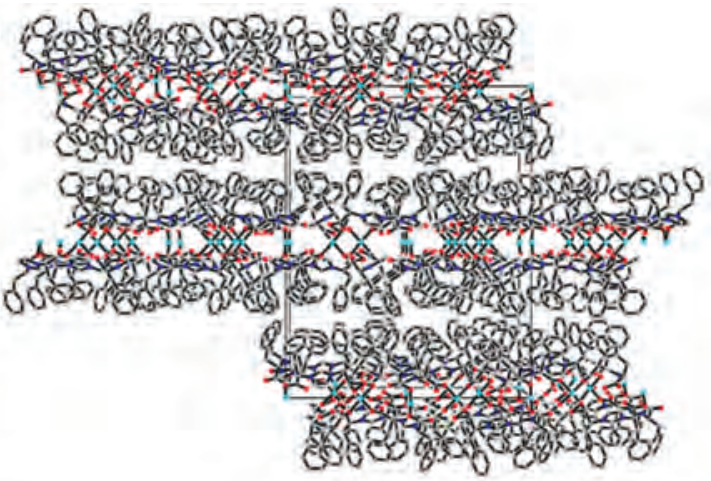

Fig. 5 (a) Crystal packing of complex 8, viewed along the $c$ axis, within the unit cell. (b) 3D arrangement of the 2D lamellar sheets, viewed along the $b$ axis.

bility, DFT calculations ${ }^{32}$ were carried out for these anions with $\mathrm{R}=\mathrm{Me},{ }^{\mathrm{i}} \mathrm{Pr}$ and $\mathrm{CH}_{2} \mathrm{Ph}$. The discussion was centred in the $S, S$ isomers. Three conformers were located for each $\left[(S, S)-\mathrm{L}^{\mathrm{R}}\right]^{-}$ anion and the corresponding structures show different orientations of the 1,3-substituted arms with respect to the imidazolium ring. Fig. 7 depicts the optimised structures of the three conformers located for the $\left[(S, S)-\mathrm{L}^{\mathrm{iPr}}\right]^{-}$anion, and those for other $\left[(S, S)-\mathrm{L}^{\mathrm{R}}\right]^{-}$anions $\left(\mathrm{R}=\mathrm{Me}\right.$ and $\left.\mathrm{CH}_{2} \mathrm{Ph}\right)$ are collected in the ESI (Fig. S8†). The maximum energy difference, measured as relative Gibbs free energy, between these conformers was computed to be $<1 \mathrm{kcal} \mathrm{mol}^{-1}$ and this fact was in agreement with the expected free rotation along the $\mathrm{C}_{\text {chiral }}-\mathrm{N}$ vector and with the miscellaneous orientations of these arms found in the structures of compounds 2, 4-6, and 8. These theoretical results confirm the conformational flexibility as ditopic linkers of the $\left[\mathrm{L}^{\mathrm{R}}\right]^{-}$ligands. Their coordination capabilities were analyzed and, for instance, the HOMO to HOMO-3 orbitals, for the most stable conformer of the $\left[\mathrm{L}^{\mathrm{iPr}}\right]^{-}$anion, display principally the in-phase and out-of-phase combinations of $\sigma \mathrm{O}$ lone pairs (Fig. S9†).

\section{Preliminary studies on asymmetric catalysis: synthesis of chiral $\alpha$-aminophosphonates}

Chiral $\alpha$-aminophosphonates, considered as phosphorus analogues of $\alpha$-amino acids, are of special interest due to their broad range of biological activities ${ }^{33}$ and their promising use in medicinal chemistry and pharmaceutical sciences. ${ }^{34}$ Among other approaches, ${ }^{35}$ the Kabachnik-Fields reaction is the most efficient method for the synthesis of $\alpha$-aminophosphonates, which is a one-pot, three-component procedure using a carbonyl compound, amine and dialkyl phosphonate, ${ }^{36}$ generally promoted by acid catalysts. ${ }^{34 b, 37}$ Despite the importance of the Kabachnik-Fields reaction, enantioselective versions for the preparation of enantiomerically enriched 

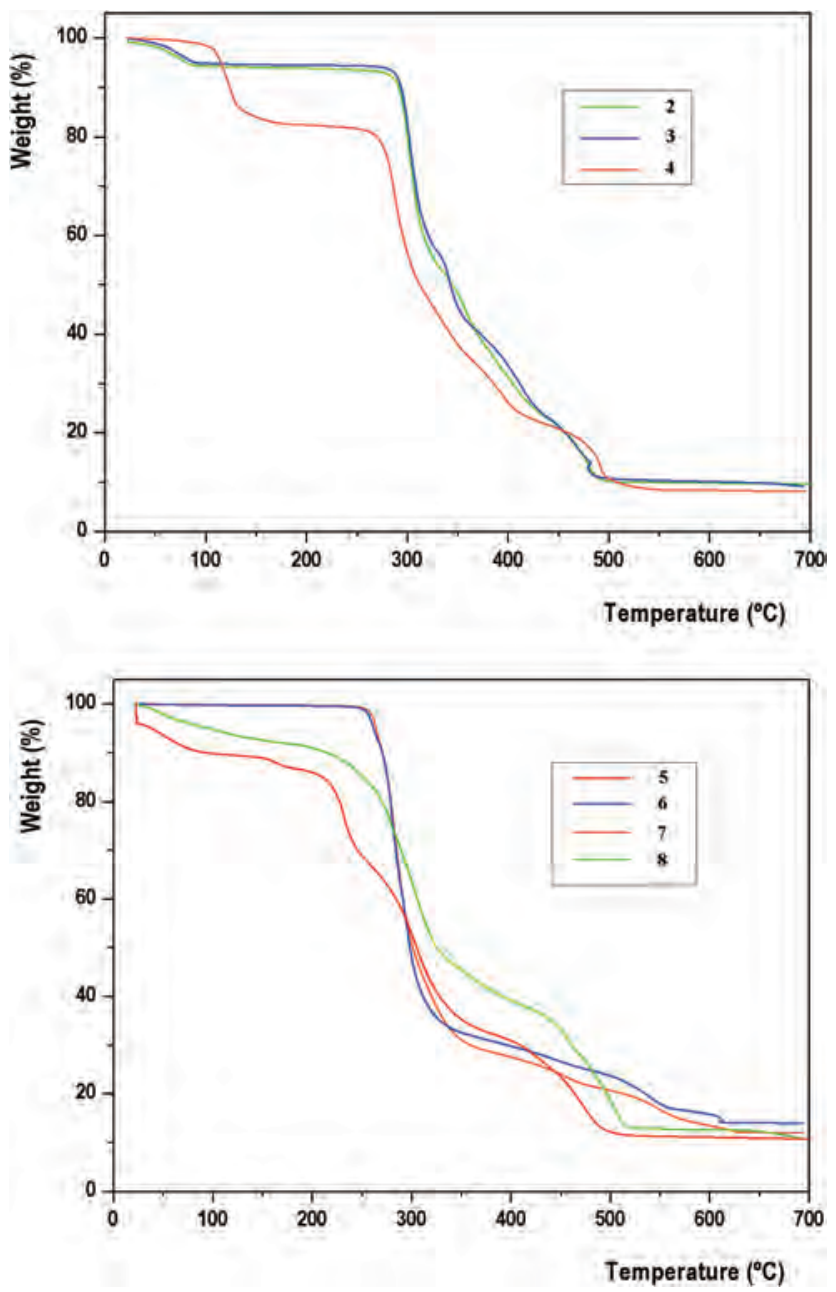

Fig. 6 Thermogravimetric analyses for zinc 2-4 (upper) and copper complexes 5-8 (bottom).

$\alpha$-aminophosphonates are scarce. ${ }^{38}$ Only a few examples have been reported, including both organocatalysis ${ }^{39}$ and metal catalysis. ${ }^{40}$ It is worth mentioning that in 2011, Ohara et al. reported an efficient method that allows the synthesis of<smiles>COc1ccc(C=O)cc1</smiles><smiles>COc1ccc(N)cc1</smiles><smiles>CCOP(=O)([IH])OCC</smiles><smiles>CCOP(=O)(OC)C(Nc1ccc(OC)cc1)c1ccc(OC)cc1</smiles>

Scheme 3 Model reaction for the synthesis of chiral $\alpha$-aminophosphonates.

enantioenriched $\alpha$-aminophosphonates using a zinc(II) complex of 1,2-bis(imidazolin-2-yl)pyridine. ${ }^{41}$ Recently, we have explored the use of imidazolium-based zwitterionic dicarboxylic ligands, $\left[\mathrm{L}^{\mathrm{R}}\right]^{-}$, as chiral inductors for the catalytic asymmetric oxidation of sulfides with hydrogen peroxide using oxoperoxo-Mo(vi) catalysts. ${ }^{42}$ On these bases, we decided to explore the use of $\mathrm{Zn}$ (II) homochiral coordination polymers 1 and 2 as catalysts in order to produce enantiomerically enriched $\alpha$-aminophosphonates. The synthetic efficiency of the Zn catalyst in the Kabachnik-Fields reaction was evaluated in the one-pot, three-component procedure using 4-methoxybenzaldehyde, 4-methoxyaniline and diethyl phosphonate as the model reaction (Scheme 3).

Table 3 reports the selected results of the reactions carried out in a reactor with a $1: 1: 1: 0.1$ ratio of aldehyde: aniline : phosphonate : catalyst. Several solvents were tested at different reaction temperatures in order to evaluate their effects on the enantioselectivity of the process. The best conversion and selectivity to the $\alpha$-aminophosphonate was obtained in toluene at $80{ }^{\circ} \mathrm{C}$, however, unfortunately, no enantioselectivity was observed in these reactions. Better enantioselectivities were obtained in $\mathrm{MeOH}$, though the ees were very low, $c a .1-5 \%$, and with poor selectivities to the $\alpha$-aminophosphonate. Particularly, in $\mathrm{MeOH}$ at $60{ }^{\circ} \mathrm{C}$ and employing catalyst 1 (entry 5 , Table 3 ), we obtained $14 \%$ of the $\alpha$-aminophosphonate with a $4.5 \%$ of enantiomeric excess. The fast on/off exchange of the ligand from the coordination sphere of $\mathrm{Zn}$ (II) is perhaps the key reason why only poor enantioselectivities are obtained using these complexes as catalysts for the Kabachnik-Fields reaction.
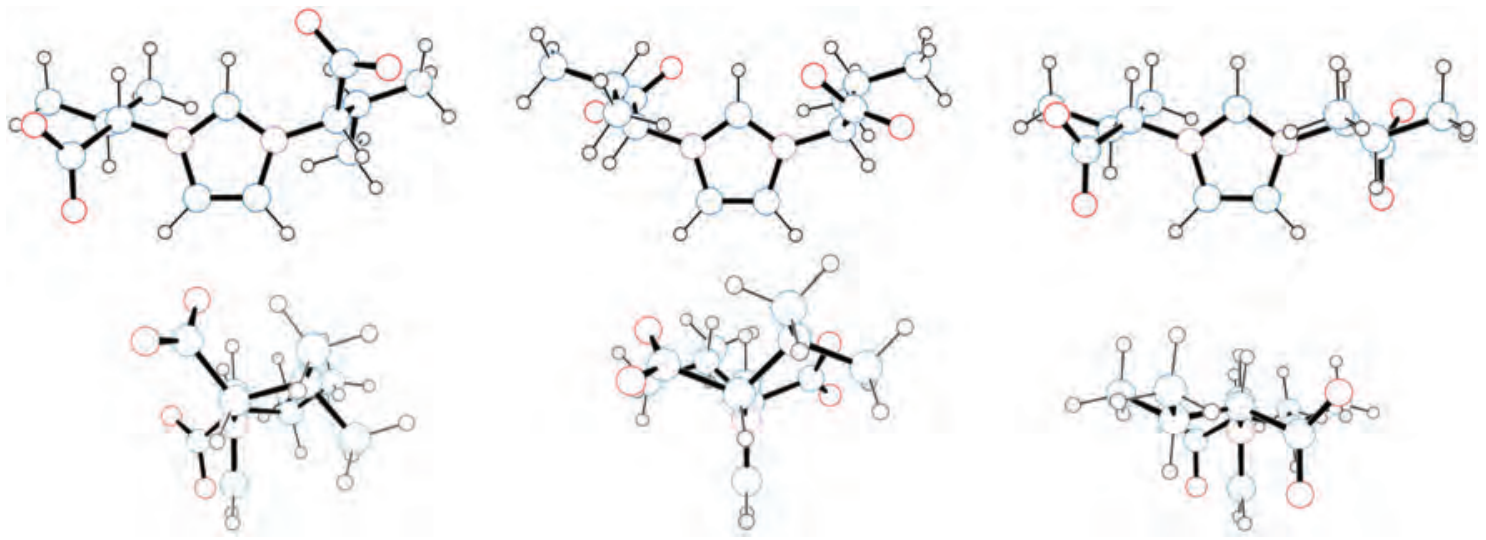

Fig. 7 Optimised structures of the three conformers located for the $\left[(S, S)-L^{\mathrm{iPr}}\right]^{-}$anion: frontal (up) and lateral views (bottom). 
Table 3 Synthesis of $\alpha$-aminophosphonates using zinc(II) coordination polymers 1 and 2 as catalysts ${ }^{a}$

\begin{tabular}{|c|c|c|c|c|c|c|c|}
\hline Entry & Catalyst & Solvent & $T\left({ }^{\circ} \mathrm{C}\right)$ & $t(\mathrm{~h})$ & Conversion $^{b}$ & Selectivity $^{b}$ & $\% \mathrm{ee}^{c}$ \\
\hline 1 & 1 & Toluene & 80 & 18 & 86 & 93 & -0.2 \\
\hline 2 & 2 & Toluene & 80 & 18 & 90 & 59 & -0.2 \\
\hline 3 & 1 & $\mathrm{CHCl}_{3}$ & 50 & 18 & 95 & 43 & +0.3 \\
\hline 4 & 2 & $\mathrm{CHCl}_{3}$ & 50 & 18 & 80 & 14 & +1 \\
\hline $5^{e}$ & $\mathbf{1}^{d}$ & $\mathrm{MeOH}$ & 60 & 18 & 99 & 53 & +2.6 \\
\hline $6^{e}$ & 1 & $\mathrm{MeOH}$ & 30 & 42 & 98 & 14 & +4.5 \\
\hline $7^{e}$ & $\mathbf{1}^{d}$ & $\mathrm{MeOH}$ & 30 & 42 & 92 & 19 & +3.3 \\
\hline
\end{tabular}

${ }^{a}$ Reaction conditions: catalyst $0.05 \mathrm{mmol}$, 4-methoxybenzaldehyde $0.5 \mathrm{mmol}$, 4-methoxyaniline $0.5 \mathrm{mmol}$, diethyl phosphonate 0.5 mmol, solvent $1.0 \mathrm{~mL} .{ }^{b}$ Determined by ${ }^{1} \mathrm{H}$ NMR analysis. ${ }^{c}$ Determined by HPLC. ${ }^{d}$ The catalyst was prepared in situ by mixing $\mathrm{Zn}(\mathrm{AcO})_{2}(0.10 \mathrm{mmol})$ and $(S, S)-\mathrm{HL}^{\mathrm{Me}}(0.20 \mathrm{mmol}){ }^{e}$ Solvent $2.0 \mathrm{~mL}$.

\section{Conclusions}

Two-dimensional homochiral coordination polymers of the general formula $\left[\mathrm{M}\left(\mathrm{L}^{\mathrm{R}}\right)_{2}\right]_{n}$ were obtained by reaction between zinc acetate or copper acetate and enantiomerically pure $\mathrm{HL}^{\mathrm{R}}$ compounds and they were characterised and structurally identified by X-ray diffraction methods (single crystal and powder). In all the zinc, 1-4, and the copper, 5-8, complexes the metals were bridged by the chiral imidazolium-based dicarboxylate ligands, $\left[\mathrm{L}^{\mathrm{R}}\right]^{-}$, through the two carboxylate groups. The observed general $\mu^{2}-\kappa^{1}-\mathrm{O}^{1}, \kappa^{1}-\mathrm{O}^{3}$ coordination mode afforded a tetrahedral metal coordination environment for zinc and a square planar one for copper complexes. DFT calculations on the $\left[\mathrm{L}^{\mathrm{R}}\right]^{-}$anions confirmed the conformational flexibility of the carboxylate arms linked to the imidazolium moiety and this fact makes these $\left[\mathrm{L}^{\mathrm{R}}\right]^{-}$ligands good ditopic linkers for the formation of different coordination polymers with four-coordinated metal centres. Although the catalytic performance of $\mathrm{Zn}$ complexes $\mathbf{1}$ and $\mathbf{2}$ in the synthesis of chiral $\alpha$-aminophosphonates is very poor, further studies are in progress in order to apply these chiral coordination polymers as catalysts in other asymmetric processes.

\section{Acknowledgements}

Financial support from the Junta de Andalucía (Proyecto de Excelencia FQM-7079) is gratefully acknowledged. R. P. C. acknowledges the Junta de Andalucía for the postdoctoral contract associated with the FQM-7079 project. We thank the Centro de Servicios de Informática y Redes de Comunicaciones (CSIRC), Universidad de Granada for providing the computing time.

\section{References}

1 Z. Fei, D. Zhao, T. J. Geldbach, R. Scopelliti and P. J. Dyson, Chem. - Eur. J., 2004, 10, 4886-4893.

2 (a) H. Debus, Justus Liebigs Ann. Chem., 1858, 107, 199-208; (b) B. Radzisewski, Ber. Dtsch. Chem. Ges., 1882, 15, 27062708 .
3 S. Kirchhecker, M. Antonietti and D. Esposito, Green Chem., 2014, 16, 3705-3709.

4 J. Sun, L. Han, W. Cheng, J. Wang, X. Zhang and S. Zhang, ChemSusChem, 2011, 4, 502-507.

5 S. J. Yang, R. Rothe, S. Kirchhecker, D. Esposito, M. Antonietti and N. Fechler, Carbon, 2015, 94, 641-645.

6 Selected examples are: (a) V. Gandin, M. Pellei, M. Marinelli, C. Marzano, A. Dolmella, M. Giorgetti and C. Santini, J. Inorg. Biochem., 2013, 129, 135-144; (b) W. A. Herrmann, L. J. Goossen and M. Spiegler, J. Organomet. Chem., 1997, 547, 357-366; (c) W.-H. Yang, C.-S. Lee, S. Pal, Y.-N. Chen, W.-S. Hwang, I. J. B. Lin and J.-C. Wang, J. Organomet. Chem., 2008, 693, 3729-3740; (d) M. Pellei, V. Gandin, M. Marinelli, C. Marzano, M. Yousufuddin, H. V. R. Dias and C. Santini, Inorg. Chem., 2012, 51, 9873-9882.

7 Selected examples are: (a) Z. Fei, W. H. Ang, T. J. Geldbach, R. Scopelliti and P. J. Dyson, Chem. - Eur. J., 2006, 12, 4014-4020; (b) Z. Fei, T. J. Geldbach, D. Zhao, R. Scopelliti and P. J. Dyson, Inorg. Chem., 2005, 44, 5200-5202; (c) Z. Fei, D. Zhao, T. J. Geldbach, R. Scopelliti, P. J. Dyson, S. Antonijevic and G. Bodenhausen, Angew. Chem., Int. Ed., 2005, 44, 5720-5725.

8 See for example: (a) P. Suresh, C. N. Babu, N. Sampath and G. Prabusankar, Dalton Trans., 2015, 44, 7338-7346; (b) P. Suresh, C. N. Babu and G. Prabusankar, Polyhedron, 2015, 89, 322-329; (c) P. Suresh, S. Radhakrishnan, C. N. Babu, A. Sathyanarayana, N. Sampath and G. Prabusankar, Dalton Trans., 2013, 42, 10838-10846; (d) B. F. Abrahams, H. E. Maynard-Casely, R. Robson and K. F. White, CrystEngComm, 2013, 15, 9729-9737.

9 Z. Fei, T. J. Geldbach, R. Scopelliti and P. J. Dyson, Inorg. Chem., 2006, 45, 6331-6337.

10 Selected examples are: (a) L. Han, S. Zhang, Y. Wang, $\mathrm{X}$. Yan and X. Lu, Inorg. Chem., 2009, 48, 786-788; (b) X. W. Wang, L. Han, T. J. Cai, Y. Q. Zheng, J. Z. Chen and Q. Deng, Cryst. Growth Des., 2007, 7, 1027-1030; (c) X.-C. Chai, Y.-Q. Sun, R. Lei, Y.-P. Chen, S. Zhang, Y.-N. Cao and H.-H. Zhang, Cryst. Growth Des., 2010, 10, 658-668.

11 D. Esposito, S. Kirchhecker and M. Antonietti, Chem. - Eur. J., 2013, 19, 15097-15100. 
12 O. Kühl and G. Palm, Tetrahedron: Asymmetry, 2010, 21, 393-397.

13 O. Kühl, S. Millinghaus and P. Wehage, Cent. Eur. J. Chem., 2010, 8, 1223-1226.

14 (a) A. Ferry, K. Schaepe, P. Tegeder, C. Richter, K. M. Chepiga, B. J. Ravoo and F. Glorius, ACS Catal., 2015, 5, 5414-5420; (b) M. A. Reynoso-Esparza, I. I. Rangel-Salas, A. A. Peregrina-Lucano, J. G. Alvarado-Rodríguez, F. A. López-Dellamary-Toral, R. Manríquez-González, M. L. Espinosa-Macías and S. A. Cortes-Llamas, Polyhedron, 2014, 81, 564-571.

15 X. Wang, X.-B. Li, R.-H. Yan, Y.-Q. Wang and E.-Q. Gao, Dalton Trans., 2013, 42, 10000-10010.

16 C. N. Babu, A. Sathyanarayana, S. M. Mobin and G. Prabusankar, Inorg. Chem. Commun., 2013, 37, 222-224.

17 L. Ma, C. Abney and W. Lin, Chem. Soc. Rev., 2009, 38, 1248-1256.

18 M. Yoon, R. Srirambalaji and K. Kim, Chem. Rev., 2012, 112, 1196-1231.

19 Bruker. APEX2, Bruker AXS Inc., Madison, Wisconsin, USA, 2007.

20 Bruker Advanced X-ray Solutions, Bruker AXS Inc., Madison, Wisconsin, USA, 2001.

21 C. M. Burla, M. Camalli, B. Carrozzini, G. L. Cascarano, C. Giacovazzo, G. Polipori and R. Spagna, SIR2002: the program, J. Appl. Crystallogr., 2003, 36, 1103.

22 G. M. Sheldrick, Acta Crystallogr., Sect. C: Cryst. Struct. Commun., 2015, 71, 3-8.

23 (a) A. L. Spek, J. Appl. Crystallogr., 2003, 36, 7-13; (b) A. L. Spek, Acta Crystallogr., Sect. D: Biol. Crystallogr., 2009, 65, 148-155; (c) A. L. Spek, Acta Crystallogr., Sect. C: Cryst. Struct. Commun., 2015, 71, 9-18.

24 A. Boultif and D. Louer, J. Appl. Crystallogr., 2004, 37, 724731.

25 H. M. Rietveld, J. Appl. Crystallogr., 1969, 2, 65-71.

26 A. C. Larson and R. B. von Dreele, General Structure Analysis System (GSAS), Los Alamos National Laboratory Report LAUR 86-748, 2004.

27 B. H. Toby, J. Appl. Crystallogr., 2001, 34, 210-213.

28 (a) A. D. Becke, J. Chem. Phys., 1993, 98, 5648-5652; (b) C. Lee, W. Yang and R. G. Parr, Phys. Rev. B: Condens. Matter, 1988, 37, 785-789.

29 M. J. Frisch, G. W. Trucks, H. B. Schlegel, G. E. Scuseria, M. A. Robb, J. R. Cheeseman, G. Scalmani, V. Barone, B. Mennucci, G. A. Petersson, H. Nakatsuji, M. Caricato, X. Li, H. P. Hratchian, A. F. Izmaylov, J. Bloino, G. Zheng, J. L. Sonnenberg, M. Hada, M. Ehara, K. Toyota, R. Fukuda, J. Hasegawa, M. Ishida, T. Nakajima, Y. Honda, O. Kitao, H. Nakai, T. Vreven, J. A. Montgomery Jr., J. E. Peralta, F. Ogliaro, M. Bearpark, J. J. Heyd, E. Brothers, K. N. Kudin, V. N. Staroverov, R. Kobayashi, J. Normand, K. Raghavachari, A. Rendell, J. C. Burant, S. S. Iyengar,
J. Tomasi, M. Cossi, N. Rega, J. M. Millam, M. Klene, J. E. Knox, J. B. Cross, V. Bakken, C. Adamo, J. Jaramillo, R. Gomperts, R. E. Stratmann, O. Yazyev, A. J. Austin, R. Cammi, C. Pomelli, J. W. Ochterski, R. L. Martin, K. Morokuma, V. G. Zakrzewski, G. A. Voth, P. Salvador, J. J. Dannenberg, S. Dapprich, A. D. Daniels, Ö. Farkas, J. B. Foresman, J. V. Ortiz, J. Cioslowski and D. J. Fox, Gaussian 09, Revision E.01, Gaussian, Inc., Wallingford CT, 2009.

30 L. Yang, D. R. Powell and R. P. Houser, Dalton Trans., 2007, 955-964.

31 Cambridge Structural Database System, Cambridge Crystallographic Data Centre, 12 Union Road, Cambridge, CB2 1EZ, UK. C. R. Groom, I. J. Bruno, M. P. Lightfoot and S. C. Ward, Acta Crystallogr., Sect. B: Struct. Sci., 2016, 72, 171-179.

32 R. G. Parr and W. Yang, Density Functional Theory of Atoms and Molecules, Oxford University Press, New York, 1989.

33 (a) P. P. Giannousis and P. A. Bartlett, J. Med. Chem., 1987, 30, 1603-1609; (b) J. Hiratake and J. Oda, Biosci., Biotechnol., Biochem., 1997, 61, 211-218; (c) E. D. Naydenova, P. T. Todorov and K. D. Troev, Amino Acids, 2010, 38, 23-30.

34 (a) A. K. Bhattacharya, D. S. Raut, K. C. Rana, I. K. Polanki, M. S. Khan and S. Iram, Eur. J. Med. Chem., 2013, 66, 146152; (b) S. A. R. Mulla, M. Y. Pathan, S. S. Chavan, S. P. Gample and D. Sarkar, RSC Adv., 2014, 4, 7666-7672.

35 (a) Y. Q. Yu, Synthesis, 2013, 45, 2545-2550; (b) Y. Zhao, X. Chen, T. Chen, Y. Zhou, S. Yin and L. Han, J. Org. Chem., 2015, 80, 62-69; (c) B. Das, G. Satyalakshmi, K. Suneel and K. Damodar, J. Org. Chem., 2009, 74, 8400-8402.

36 (a) N. S. Zefirov and E. D. Matveeva, ARKIVOC, 2008, 2008, 1-17; (b) G. Keglevich and E. Bálint, Molecules, 2012, 17, 12821-12835.

37 T. Akiyama, M. Sanada and K. Fuchibe, Synlett, 2003, 14631464.

38 J.-A. Ma, Chem. Soc. Rev., 2006, 35, 630-636.

39 (a) L. Wang, S. M. Cui, W. Meng, G. W. Zhang, J. Nie and J. A. Ma, Chin. Sci. Bull., 2010, 1729-1731; (b) W. Xu, S. Zhang, S. Yang, L. H. Jin, P. S. Bhadury, D. Y. Hu and Y. Zhang, Molecules, 2010, 15, 5782-5796; (c) P. S. Reddy, M. V. K. Reddy and P. V. G. Reddy, Chin. Chem. Lett., 2016, 27, 943-947; (d) X. Cheng, R. Goddard, G. Buth and B. List, Angew. Chem., Int. Ed., 2008, 47, 5079-5081; (e) P. B. Thorat, S. V. Goswami, R. L. Magar, B. R. Patil and S. R. Bhusare, Eur. J. Org. Chem., 2013, 5509-5516.

40 X. Zhou, D. Shang, Q. Zhang, L. Lin, X. Liu and X. Feng, Org. Lett., 2009, 11, 1401-1404.

41 M. Ohara, S. Nakamura and N. Shibata, Adv. Synth. Catal., 2011, 353, 3285-3289.

42 C. J. Carrasco, F. Montilla and A. Galindo, Catal. Commun., 2016, 84, 134-136. 